NBER WORKING PAPER SERIES

\title{
WHY DOESN'T CAPITAL FLOW FROM RICH TO POOR COUNTRIES? AN EMPIRICAL INVESTIGATION
}

\author{
Laura Alfaro \\ Sebnem Kalemli-Ozcan \\ Vadym Volosovych \\ Working Paper 11901 \\ http://www.nber.org/papers/w11901 \\ NATIONAL BUREAU OF ECONOMIC RESEARCH \\ 1050 Massachusetts Avenue \\ Cambridge, MA 02138 \\ December 2005
}

Corresponding author: Sebnem Kalemli-Ozcan, Department of Economics, University of Houston, Houston, TX, 77204 (e-mail: Sebnem.Kalemli-Ozcan@mail.uh.edu). We thank Rawi Abdelal, Daron Acemoglu, Dan Berkowitz, Rafael Di Tella, Alex Dyck, Simon Johnson, Michael Klein, Aart Kraay, Robert Lucas, Dani Rodrik, Ken Rogoff, Julio Rotemberg, Bent Sorensen, Federico Sturzenegger, two anonymous referees, and participants at various seminars and conferences for their valuable comments and suggestions. We are grateful to Doug Bond, Philip Lane, Norman Loayza, Gian Maria Milesi-Ferretti, and Shang-Jin Wei for kindly providing us with their data. The views expressed herein are those of the author(s) and do not necessarily reflect the views of the National Bureau of Economic Research.

(C)2005 by Laura Alfaro, Sebnem Kalemli-Ozcan, and Vadym Volosovych. All rights reserved. Short sections of text, not to exceed two paragraphs, may be quoted without explicit permission provided that full credit, including (C) notice, is given to the source. 
Why Doesn't Capital Flow from Rich to Poor Countries? An Empirical Investigation Laura Alfaro, Sebnem Kalemli-Ozcan, and Vadym Volosovych

NBER Working Paper No. 11901

December 2005

JEL No. F21, F41, O1

\title{
$\underline{\text { ABSTRACT }}$
}

We examine the empirical role of different explanations for the lack of flows of capital from rich to poor countries the "Lucas Paradox." The theoretical explanations include differences in fundamentals across countries and capital market imperfections. We show that during 1970-2000 low institutional quality is the leading explanation. For example, improving Peru's institutional quality to Australia's level, implies a quadrupling of foreign investment. Recent studies emphasize the role of institutions for achieving higher levels of income, but remain silent on the specific mechanisms. Our results indicate that foreign investment might be a channel through which institutions affect long-run development.

\author{
Laura Alfaro \\ Harvard Business School \\ lalfaro@hbs.edu \\ Sebnem Kalemli-Ozcan \\ University of Houston \\ Department of Economics \\ Houston, TX 77204 \\ and NBER \\ skalemli@mail.uh.edu \\ Vadym Volosovych \\ University of Houston \\ vvolosovych@gmail.com
}




\section{Introduction}

The standard neoclassical theory predicts that capital should flow from rich to poor countries. Under the usual assumptions of countries producing the same goods with the same constant returns to scale production technology using capital and labor as factors of production, differences in income per capita reflect differences in capital per capita. Thus, if capital were allowed to flow freely, new investments would occur only in the poorer economy, and this would continue to be true until the return to investments were equalized in all the countries. However, in his now classic example, Lucas (1990) compares the U.S. and India in 1988 and demonstrates that, if the neoclassical model were true, the marginal product of capital in India should be about 58 times that of the U.S. In face of such return differentials, all capital should flow from the U.S. to India. In practice, we do not observe such flows. Lucas questions the validity of the assumptions that give rise to these differences in the marginal product of capital and asks what assumptions should replace these. According to Lucas, this is the central question of economic development.

Lucas' work has generated an extensive theoretical literature. Researchers, including Lucas himself, show that with slight modifications of the standard neoclassical theory, the "Paradox" disappears. These theoretical explanations for the "Lucas Paradox" can be grouped into two categories. The first group includes differences in fundamentals that affect the production structure of the economy, such as technological differences, missing factors of production, government policies, and the institutional structure. ${ }^{1}$ The second group of explanations focuses on international capital market imperfections, mainly sovereign risk and asymmetric information. Although capital has a high return in developing countries, it does not go there because of the market failures. ${ }^{2}$ According to Lucas, international capital market failures, or "political risk" as he puts it, cannot explain the lack of flows before 1945 since during that time most of the "third world" was subject to European legal arrangements imposed through colonialism. Hence, investors in the developed countries, such as the U.K., could expect contracts to be enforced in the same way in both the U.K. and India. ${ }^{3}$

\footnotetext{
${ }^{1}$ See King and Rebelo (1993), Razin and Yuen (1994), Gomme (1993), and Tornell and Velasco (1992). Lucas finds that accounting for the differences in human capital quality across countries significantly reduces the return differentials and considering the role of human capital externalities eliminates the return differentials. However, his calculations assume that the externalities from the country's stock of human capital accrue entirely to the producers within the country, i.e., all knowledge spillovers are local. This assumption is at odds with the evidence of quantitatively significant international knowledge spillovers; see Helpman (2004).

${ }^{2}$ See Gertler and Rogoff (1990) and Gordon and Bovenberg (1996).

${ }^{3}$ Before 1945 European imperial powers granted trading rights to monopoly companies, an action that created one-way flows. In theory a large capital exporting economy can limit capital flows in order to push interest rates in a favorable direction. Gordon and Bovenberg (1996) note that there is little evidence of large countries restrict capital flows for this purpose.
} 
However, the British institutions in India do not necessarily have the same quality as the British institutions in the U.S. and Australia. As shown by Acemoglu, Johnson, and Robinson (2001, 2002), if European settlement was discouraged by diseases or if surplus extraction was more beneficial, then the European colonizers set up an institutional structure where the protection of property rights was weak.

Our objective in this paper is to investigate the role of the different theoretical explanations for the lack of flows of capital from rich countries to poor countries in a systematic empirical framework. ${ }^{4}$ We show that during the period 1970-2000 low institutional quality is the leading explanation for the "Lucas Paradox." The ordinary least squares (OLS) estimates show that improving the quality of institutions to the U.K.'s level from that of Turkey's implies a $60 \%$ increase in foreign investment. The instrumental variable (IV) estimates imply an even larger effect: improving Peru's institutional quality to Australia's level, implies a quadrupling of foreign investment. ${ }^{5}$

An excellent example for the role of institutional quality in attracting foreign capital is Intel's decision to locate in Costa Rica in $1996 .{ }^{6}$ In the final stage of the decision process, the short list included Mexico and Costa Rica. The two countries have similar GDP per capita in U.S. dollars (close to $\$ 3000$ at that time), albeit Mexico is a much larger country. Both countries have similar levels of adult literacy rates. However, given the overall size of Intel's investment relative to the size of the economy, one important concern in the decision process was the absolute availability of engineers and technically trained graduates, which favored Mexico. Hence, one cannot argue that human capital was a defining issue in Intel's final choice. Instead, Costa Rica's stability and lower corruption levels tilted the balance in favor of the country. As noted by Spar (1998), Mexico's offer to make "exceptions" to the existing rules for Intel only in contrast to Costa Rica's approach of making any concession made to Intel available to all other investors was an important reason in the final decision. Another example is the recent boom in foreign direct investment (FDI) in Turkey. This boom is similar to what Portugal and Greece observed after joining in the EU. Turkey became an official accession country on October 3rd, 2005 and started entry negotiations. In a recent article, Champion and von Reppert-Bismarck (2005), argue that these official entry negotiations would force Turkey to become more like the "EU countries" in its banking sector, its antitrust law, its regulation, and its policies, which in turn will attract foreign investment. Turkey has undertaken

\footnotetext{
${ }^{4}$ Obstfeld (1995) argues that the most direct approach would be to compare capital's rate of return in different countries. Unfortunately, it is difficult to find internationally comparable measures of after tax returns to capital.

${ }^{5}$ Both Turkey and Peru are in the bottom 25th percentile in the distribution of the index of institutions, whereas Australia and the U.K. are in the top 75th percentile.

${ }^{6}$ See Spar (1998) and Larrain, Lopez-Calva and Rodriguez-Clare (2000).
} 
major institutional reform and constitutional change in the past 2 years, including the 2003 FDI law that cuts the official procedures from 15 to 3 for foreign investors. Multinational companies such as Metro AG, PSA Peugeot Citroen, Vodafone PLC, and France Telekom are increasing their FDI to Turkey, arguing that the investor protection and overall investment climate improved considerably as a result of these reforms. As a result, FDI flows has boomed from an average of well under $\$ 1$ billion in the 1990s to $\$ 2.6$ billion in last year and more than a $\$ 5$ billion projected for 2005 .

The "Lucas Paradox" is related to the major "puzzles" in international macroeconomics and finance. ${ }^{7}$ These include the high correlation between savings and investment in OECD countries (the Feldstein-Horioka puzzle); the lack of overseas investment by the home country residents (the home bias puzzle); and the low correlations of consumption growth across countries (the risk sharing puzzle). All of these puzzles stem from the lack of international capital flows, more specifically, the lack of international equity holdings. However, the empirical literature on these issues is extremely thin and not in agreement. In particular, we still do not know what is more important in explaining the "Lucas Paradox": fundamentals or market failures? Some researchers provide indirect historical evidence that schooling, natural resources, and demographic factors are the reasons for the European investment into the "new world." 8 The empirical literature on the determinants of capital flows has focused on the role of external (push) and internal (pull) factors. Researchers find that external factors, mostly low interest rates in the developed nations, in particular in the U.S., played an important role in accounting for the renewal of foreign lending to developing countries in the 1990s. ${ }^{9}$ The literature pays particular attention to the determinants of FDI and shows that government size, political stability, and openness play an important role. ${ }^{10}$ In terms of the determinants of bilateral equity flows and external debt some studies find support for theories emphasizing imperfections in international credit markets. ${ }^{11}$ These papers, however, have not paid particular attention to the role of institutions in shaping international capital flows over the long-run. ${ }^{12}$

\footnotetext{
${ }^{7}$ See Obstfeld and Rogoff (2000) for an overview of the major puzzles in international economies.

${ }^{8}$ In the context of British overseas investment before World War I, O'Rourke and Williamson (1999) find that British capital chased European emigrants, where both were seeking cheap land and natural resources. Clemens and Williamson (2004), using data on British investment in 34 countries during 19th century, show that two thirds of the British capital exports went to the labor-scarce new world and only about one quarter of it went to labor abundant Asia and Africa because of similar reasons.

${ }^{9}$ See Calvo, Leiderman and Reinhart (1996).

${ }^{10}$ See Edwards (1991) and Wei and Wu (2002).

${ }^{11}$ See Lane (2004) and Portes and Rey (2005).

${ }^{12}$ Using firm-level data Stulz (2005) and Doidge, Karolyi and Stulz (2004) show that the institutions of the country in which a firm is located affect how investors receive a return from investing in the firm. Specifically, they show that almost all of the variation in governance ratings across firms in less developed countries is attributable to country characteristics. The implication of their work is that weak institutions at the country-level can explain the lack of
} 
Our paper is also related to the recent work on economic development that emphasizes the role of institutions for achieving higher levels of income. ${ }^{13}$ However there is little systematic evidence on the specific mechanisms. Our results show institutional quality shaped international capital flows in the last thirty years, which in turn implies that foreign investment can be one of the missing links through which institutions affect long-run development. ${ }^{14}$

The rest of the paper is organized as follows. Section 2 reviews the standard neoclassical model and presents the main empirical implications in terms of capital movements. Section 3 investigates the role of the different theoretical explanations of the "Lucas Paradox" in a cross-country regression framework. Section 4 concludes.

\section{Conceptual Issues}

Assume a small open economy where output is produced using capital $K$ and labor $L$ via a CobbDouglas production function,

$$
Y_{t}=A_{t} F\left(K_{t}, L_{t}\right)=A_{t} K_{t}^{\alpha} L_{t}^{1-\alpha} \quad F_{K}(.)>0, F_{L}(.)>0 ; F_{K K}(.)<0, F_{L L}(.)<0,
$$

where $Y$ denotes output and $A$ denotes the total factor productivity (TFP). Agents can borrow and lend capital internationally. If all countries share a common technology, perfect capital mobility implies the instantaneous convergence of the returns to capital. Hence, for countries $i$ and $j$,

$$
A_{t} f^{\prime}\left(k_{i t}\right)=r_{t}=A_{t} f^{\prime}\left(k_{j t}\right)
$$

where $f($.$) is the net of depreciation production function in per capita terms and k$ denotes capital per capita. Diminishing returns to capital implies that in the transition process, resources will flow from capital abundant countries (low returns) to capital scarce countries (high returns). Although widely used in the growth literature, the neoclassical model with constant TFP has counterfactual implications for rates of return since not enough capital seems to flow to capital scarce countries and implied interest rates do not seem to converge. As explained in the introduction, the theoretical explanations for this paradoxical pattern can be grouped as differences in fundamentals across

\footnotetext{
flows to countries where the physical marginal product of capital is the highest, a corollary on which we provide systematic evidence.

${ }^{13}$ See North (1981, 1994, 1995), Hall and Jones (1999), and Acemoglu, Johnson and Robinson (2001, 2002).

${ }^{14}$ Klein (2005) shows that the effect of capital account liberalization on growth depends on the institutional development of a country.
} 
countries versus international capital market imperfections. We investigate each group in detail below.

\section{$2.1 \quad$ Fundamentals}

Missing Factors of Production

One of the explanations for the lack of capital flows from rich to poor countries is the existence of other factors - such as human capital and land - that positively affect the returns to capital but are generally ignored by the conventional neoclassical approach. For example, if human capital positively affects capital's return, less capital tends to flow to countries with lower endowments of human capital. Thus, if the production function is in fact given by

$$
Y_{t}=A_{t} F\left(K_{t}, Z_{t}, L_{t}\right)=A_{t} K_{t}^{\alpha} Z_{t}^{\beta} L_{t}^{1-\alpha-\beta},
$$

where $Z_{t}$ denotes another factor that affects the production process, then (2) misrepresents the implied capital flows. Hence, for countries $i$ and $j$ the true return is

$$
A_{t} f^{\prime}\left(k_{i t}, z_{i t}\right)=r_{t}=A_{t} f^{\prime}\left(k_{j t}, z_{j t}\right)
$$

\section{Government Policies}

Government policies can be another impediment to the flows and the convergence of the returns. For example, differences across countries in government tax policies can lead to substantial differences in capital-labor ratios. Inflation may work as a tax and decrease the return to capital. In addition, the government can explicitly limit capital flows by imposing capital controls. We can model the effect of these distortive government policies by assuming that governments tax capital's return at a rate $\tau$, which differs across countries. Hence, for countries $i$ and $j$, the true return is

$$
A_{t} f^{\prime}\left(k_{i t}\right)\left(1-\tau_{i t}\right)=r_{t}=A_{t} f^{\prime}\left(k_{j t}\right)\left(1-\tau_{j t}\right) .
$$

Institutional Structure and Total Factor Productivity

Institutions are the rules of the game in a society. They consist of both informal constraints (traditions, customs) and formal rules (rules, laws, constitutions). They shape the structure of 
an economy. North (1994) defines institutions as the humanly devised constraints that structure political, economic, and social interaction. There is an important distinction between policies and institutions. Policies are choices made within a political and social structure, i.e., within a set of institutions.

Institutions are understood to affect economic performance through their effect on investment decisions by protecting the property rights of entrepreneurs against the government and other segments of the society and preventing elites from blocking the adoption of new technologies. In general, weak property rights due to poor institutions can lead to lack of productive capacities or uncertainty of returns in an economy. Thus institutional weaknesses create a wedge between expected returns and ex-post returns. We model these as differences in the parameter $A_{t}$, which captures differences in overall efficiency in the production across countries. In defining the parameter $A_{t}$, we cannot differentiate between the effect of institutions on investment opportunities versus that of the TFP (i.e., $A_{t}$ defined as the incentive structure that allows for innovations versus $A_{t}$ defined as the productivity index). Indeed, as Prescott (1998) argues, the efficient use of the existing technology or the resistance to the adoption of new ones depends on the "arrangements" a society employs. Eichengreen (2003) argues that capital-labor ratios across countries might differ because of differences in cultural context and/or technological capacity. Although technology is available to all countries, there might be barriers to adoption of the existing technologies, or differences in the efficient use of the same technology. ${ }^{15,16}$

Hence, for countries $i$ and $j$, the true return is given by,

$$
A_{i t} f^{\prime}\left(k_{i t}\right)=r_{t}=A_{j t} f^{\prime}\left(k_{j t}\right)
$$

\subsection{International Capital Market Imperfections}

\section{Asymmetric Information}

Asymmetric information problems, intrinsic to capital markets, can be ex-ante (adverse selection), interim (moral hazard) or ex-post (costly state verification). In general, under asymmetric information, the main implications of the neoclassical model regarding the capital flows tend not to hold. In a model with moral hazard, for example, where lenders cannot monitor borrowers'

\footnotetext{
${ }^{15}$ See Parente and Prescott (2000) and Rajan and Zingales (2003).

${ }^{16}$ Kalemli-Ozcan, Reshef, Sorensen, and Yosha (2003) show that capital flows to high productivity states within the U.S., where there is a common institutional structure. This result is consistent with the prediction of a neoclassical model with TFP differences.
} 
investment, poor countries' per capita investment depends positively on per capita wealth. Alternatively, if foreign investors are handicapped in terms of domestic market information, they tend to under-invest.

\section{Sovereign Risk}

Sovereign risk is defined as any situation where a sovereign defaults on loan contracts with foreigners, seizes foreign assets located within its borders, or prevents domestic residents from fully meeting obligations to foreign contracts. ${ }^{17}$ The problem stems from the fact that repayment incentives for debtors might differ from what is in a contract between two nations because the ability of a court to force a sovereign entity to comply is extremely limited.

Lucas, citing the specific example of India, dismisses sovereign risk as an explanation for the lack of flows from rich to poor countries. He maintains that investors in India faced the same rules and regulations as the investors in the U.K. However, as Reinhart and Rogoff (2004) argue, the numerous rebellions in India while a British colony indicate that the perceived ex-ante risk of expropriation was greater than the ex-post one. Reinhart and Rogoff (2004) emphasize the relationship between sovereign risk and historical defaults and conclude that sovereign risk must be the explanation for the "Lucas Paradox." They argue the following: "[T] he fact that so many poor countries are in default on their debts, that so little funds are channeled through equity, and that overall private lending rises more than proportionately with wealth, all strongly support the view that political risk is the main reason why we do not see more capital flows to developing countries. If credit market imperfections abate over time due to better institutions, human capital externalities or other "new growth theory" elements may come to play a larger role." This argument is fully consistent with our result since historical defaults are indicators of poor quality of the early institutions. ${ }^{18}$

\footnotetext{
${ }^{17}$ Lucas discusses monopoly power and capital controls, i.e., distortive government policies under capital market imperfections since he combines domestic and international capital market imperfections. Following Obstfeld and Rogoff (1995), we considered international capital market imperfections only those related to sovereign enforcement problems or those based on information asymmetries. We put all domestic distortions under fundamentals since they affect capital's productivity.

${ }^{18}$ In fact, we are sympathetic to the view that institutions may account for both weak fundamentals and capital market imperfections since historically weak institutions might be responsible for historical and current sovereign risk and high probability of default.
} 


\title{
3 Institutions and the "Lucas Paradox:" OLS Estimates
}

\subsection{Data and Descriptive Statistics}

\author{
Capital Flows
}

The International Financial Statistics (IFS) issued by the International Monetary Fund (IMF) is the standard data source for annual capital inflows. Although there are other data sources, the IMF, IFS provides the most comprehensive and comparable data on international capital flows. ${ }^{19}$ The main categories of capital inflows are foreign direct investment (FDI), portfolio equity investment, and debt inflows. FDI data include greenfield investments (construction of new factories), equity capital, reinvested earnings, other capital and financial derivatives associated with various intercompany transactions between affiliated enterprises. Portfolio equity investment include shares, stock participations, and similar documents that usually denote ownership of equity. When a foreign investor purchases a local firm's securities without a controlling stake, the investment is regarded as a portfolio investment. FDI is equity participation giving a controlling stake. ${ }^{20}$ In the regression analysis, we do not distinguish between minority and majority shareholders, as this distinction is not important to our analysis. In addition, because of missing portfolio data (some countries tend not to receive portfolio flows, in part due to lack of functioning stock markets), we prefer to use total foreign equity flows in the analysis, which is the sum of inflows of direct and portfolio equity investment.

Debt inflows include bonds, debentures, notes, and money market or negotiable debt instruments. We prefer to abstract most of our analysis from debt flows since they tend to be shaped by government decisions to a greater extent than flows of equity. ${ }^{21} \mathrm{We}$, on the other hand, would like to capture market decisions. ${ }^{22}$ Ideally, we would like to use all of the private capital flows and abstract the public part of debt flows. These data, however, is not available. The IMF, IFS data include both private and public issuers and holders of debt securities. Although the data are further

\footnotetext{
${ }^{19}$ All the data that are discussed in this section are described in greater detail in appendix A.

${ }^{20}$ The IMF classifies an investment as direct if a foreign investor holds at least 10 percent of a local firm's equity while the remaining equity purchases are classified under portfolio equity investment. Recently most of the FDI has been in the form of mergers \& acquisitions instead of greenfield investments.

${ }^{21}$ Until the mid 1970s - following the shutting down of the international markets in the 1930s - debt flows to most developing countries were generally restricted to international organizations/government-to-government loans. During the late 1970s, banks replaced governments of industrial countries as lenders to developing countries. After 1982, following the debt crisis, official creditors once again dominated lending to developing countries.

${ }^{22}$ In many countries bank loans have usually been intermediated through poorly regulated financial systems, hence not responding to market incentives. See Henry and Lorentzen (2003) and Obstfeld and Taylor (2004).
} 
divided by monetary authorities, general government, banks and other sectors, this information is unfortunately not available for most countries for long periods of time. In addition, it is difficult to divide the available data by private/public creditor and debtor. ${ }^{23}$ On the other hand, one might fear that excluding debt inflows totally will reduce measures of capital inflows for countries with limited stock market development and/or for countries that receive low levels of FDI, which in turn might bias our results. We argue that the role of total equity (direct and portfolio) flows for the developing countries is not small at all. For the developing countries, average inflows of FDI per capita grew by $6.2 \%$ over the last thirty years and became the main source of private capital during the 1990s. Average inflows of portfolio equity per capita grew by $9.3 \%$. Average inflows of debt per capita grew only by $3.3 \%$. We, nevertheless, examine the role of debt inflows in our robustness section.

Another issue about the IMF, IFS capital flows data is related to the importance of valuation effects. As Obstfeld (2004) notes, "an increasingly serious inadequacy of the standard current account measure is that it does not incorporate potentially large valuation effects." The IFS reports BOP transactions as flows of equity and debt. The recent literature draws attention to the significant role of capital gains and losses, defaults, price and exchange rate fluctuations, i.e., on valuation effects, as an international financial adjustment mechanism. ${ }^{24}$ Kraay, Loayza, Serven, and Ventura (2000, 2005) (KLSV) and Lane and Milesi-Ferretti $(1999,2001)$ (LM) construct estimates of foreign assets and liabilities and their subcomponents for different countries in the 1970s, 1980s, and 1990s, paying particular attention to these valuation effects, thus providing a better "tracking device" of a country's external position. These authors perform a meticulous job of cleaning the existing data. LM estimate stocks of portfolio equity and foreign direct investment based on the IMF, IFS flow data. In order to estimate FDI stocks, the authors cumulate flows and adjust for the effects of exchange rate changes. For portfolio equity stocks, they adjust for changes in the end of year U.S. dollar value of the domestic stock market. KLSV argue against the valuation of stocks using stock market prices maintaining that capital listed on the stock market and the corresponding

\footnotetext{
${ }^{23}$ The World Bank's Global Development Finance database, which focuses on the liability side, divides debt data by the type of creditor (official and private) but not by the type of debtor. These data are available only for developing countries. As Lane and Milesi-Ferretti (2001) note, for developing countries there are discrepancies between the loan flows reported in the IMF BOP Statistics and the changes in the external debt stocks as reported by the World Bank's Global Development Finance Database. Following the debt 1980s debt crisis, there are a number of measurement problems related to different methodologies for recording non-payments, rescheduling, debt forgiveness, and reductions.

${ }^{24}$ Obstfeld (2004) compares two cases. In one case, firms with equity held by foreigners pay dividends. In the second case, firms with equity held by foreigners retain earnings. In the first case, paying dividends would show up in the current account as a service import (net factor income). In the second case, a firm's stock market price would rise but there would be no record in the balance of payments under the current accounting method.
} 
share prices - especially in developing countries - are not representative of the stock of capital of a country. Instead, they use the price of investment goods in local currency, which is the investment deflator. They also adjust for exchange rate changes as in the LM data set. Both KLSV and LM data-sets are higher quality since the respective authors put extreme care on cleaning the basic IFS data, checking individual country sources and so forth.

We use capital inflows data from these three different sources in our empirical analysis. We calculate annual inflows of direct and portfolio equity investment out of the stocks in the KLSV and LM data sets as the yearly change in the stock of foreign claims on domestic capital. The inflows of direct investment from the IMF (which KLSV and LM data are based on), include reinvested earnings of foreign-owned firms, while data on inflows of portfolio equity investment do not. As KLSV point out, changes in the stock market valuation of equities will reflect these reinvested earnings while changes in the investment deflator valuation will not. Hence, KLSV procedure will underestimate the claims on portfolio equity investment. We believe the weakness of the stock market data for developing countries to be of greater concern and hence use KLSV data in most of our analysis.

Table 1 shows descriptive statistics on 81 countries during 1970-2000 from the IMF data; 58 countries between 1970-1997 from the KLSV data; and 56 countries between 1970-1998 from the LM data. These countries constitute our "base" samples for each data set. The "base" sample countries are selected out of available data for our variables of interest, which are 98,61, and 60 countries in each data set respectively, since the "base" sample countries are the ones where data are available for all the main explanatory variables. In all our regressions the dependent variable is the inflows of direct and portfolio equity investment per capita, averaged over the relevant sample period. We believe per capita measures are more in line with the theoretical literature. ${ }^{25}$ We use the average inflows to capture the long-run effects of the various explanations of the "Lucas Paradox."

Average inflows of direct and portfolio equity investment per capita has a mean of 117.34 with a standard deviation of 170.29 for the IMF sample; 38.57 with a standard deviation of 59.27 for the KLSV sample; and 202.29 with a standard deviation of 322 for the LM sample. Notice that the IMF and LM data are in 1996 constant U.S. dollars and KLSV data are in 1990 constant U.S. dollars. All three data sets show large amount of variation, where some countries receive 1000 times more flows than the others. Explanatory variables also show similarly large variation, which we

\footnotetext{
${ }^{25} \mathrm{In}$ addition a histogram revealed that this measure is more normally distributed than the other potential measures.
} 
explain in detail below.

\section{"Lucas Paradox" and the Fundamentals}

Figure 1 shows inflows of direct and portfolio equity investment for 23 developed and 75 developing countries during 1970-2000. The difference between the two is a stark demonstration of north-north flows, or the "Lucas Paradox." We use the logarithm of GDP per capita (PPP) in 1970 on the right hand side in each regression to capture the "Lucas Paradox", in other words, the positive significance of this variable demonstrates the presence of the "Paradox." Then we include the other explanatory variables. We analyze which one makes the logarithm of GDP per capita in 1970 insignificant when included, hence providing an explanation for the "Lucas Paradox."26

To capture fundamentals we use the logarithm of the average years of total schooling and average institutional quality, where both of these variables are averaged over the relevant sample period. The measurement of institutional quality is a challenging task. As argued by Acemoglu, Johnson, and Robinson (2001), there is a "cluster of institutions," including constraints on government expropriation, independent judiciary, property rights enforcement, and institutions providing equal rights and ensuring civil liberties, that are important to encourage investment and growth. Thus we construct a yearly composite index using International Country Risk Guide's (ICRG) variables from the PRS Group. ${ }^{27}$ The composite index is the sum of the indices of investment profile, government stability, internal conflict, external conflict, no-corruption, non-militarized politics, protection from religious tensions, law and order, protection from ethnic tensions, democratic accountability, and bureaucratic quality. This index takes values from 0 to 10 for each country, where a higher score means lower risk. ${ }^{28}$

\footnotetext{
${ }^{26}$ Note that upon the inclusion of the other explanatory variables, the insignificance of the log GDP per capita in 1970 is the sufficient condition for the "Paradox" to disappear. Everything else equal, the neoclassical theory implies a negative relationship between the initial capital stock (or the initial output) and the future inflows only if the countries are at the same technological development level. Unfortunately data does not allow us to control for the cross-country differences in technology other than the addition of the Solow residual as an extra control. See appendix D for a related exercise.

${ }^{27}$ The International Country Risk Guide (ICRG) data are not based on opinion surveys of any kind. The ICRG model for forecasting financial, economic, and political risk was created in 1980 by the editors of "International Reports", a weekly newsletter on international finance and economics. The editors created a statistical model to calculate country risks, which later turned into a comprehensive system that enables measuring and comparing various types of country level economic and political risks. In 1992, ICRG (its editor and analysts) moved from "International Reports" to "The PRS Group". Now, "The PRS Group's" professional staff assigns scores for each category to each country.

${ }^{28}$ The previous ICRG classification (1982-1995) included risk of government repudiation of contracts and risk of expropriation, both of which are used by Acemoglu, Johnson, and Robinson (2001). After 1995 these variables are reported under ICRG's investment profile category.
} 
Theoretical papers show that low levels of human capital and weak institutions dampen the productivity of capital. Thus, we expect these variables to be positively significant. As shown in table 1, GDP per capita (PPP) in 1970, average institutional quality and average years of schooling show large variation. GDP per capita in 1970 varies between 500 PPP U.S. dollars to 23,000 PPP U.S. dollars; and the most educated country has 11 years of schooling as opposed to 0 in the least educated country. For the institutional quality variable we have countries with strong institutions in the 75 percentile of the distribution such as U.K. and Denmark and also countries with weak institutions in the 25 percentile of the distribution such as Turkey and Mexico. Because our samples are composed of poor and rich countries, there is large variation in all of these explanatory variables, which in turn allows us to test for various explanations behind the "Lucas Paradox" in a cross-country setting.

We also use an additional variable, restrictions to capital mobility, as a measure of a government's explicit restriction to free capital mobility. This measure is the average of four dummy variables constructed by the IMF: exchange arrangements, payments restrictions on current transactions and on capital transactions, and repatriation requirements for export proceeds, where each dummy takes a value of 1 if there is the restriction. These restrictions vary between 0 and 1 , as shown in table 1 and we expect this variable to be negatively significant. Since many countries liberalized their capital accounts throughout our sample period, we also run our cross-country regressions for each decade in our sample, as shown in appendix D. This exercise will capture the changing nature of the restrictions to capital mobility variable.

\section{International Capital Market Imperfections}

It is difficult to obtain the appropriate information (from an investment point of view) about a country without visiting the country and therefore how far away that country is located could be a concern. Portfolio managers and investment bankers, who advise their clients about investing in China, for example, advertise themselves by pointing out how frequently they visit the country. As Adam Smith noted, "In the home trade, his capital is never so long out of his sight as it frequently is in the foreign trade of consumption. He can know better the character and situation of the persons whom he trusts, and if he should happen to be deceived, he knows better the laws of the country from which he must seek redress." ${ }^{29}$ Recently distance has been used a proxy for the international capital market failures, mainly asymmetric information. Analyzing the equity holdings of a large

\footnotetext{
${ }^{29}$ Adam Smith (1976, p. 454) quoted in Gordon and Bovenberg (1996).
} 
sample of actively managed mutual funds in the U.S., Coval and Moskowitz $(1999,2001)$ find that fund managers earn substantially abnormal returns in geographically proximate investments (within a 100 kilometers of a fund's headquarters). The authors interpret the results as fund managers exploiting informational advantages in their selection of nearby stocks. Portes and Rey (2005) use a similar interpretation of distance in the context of bilateral capital flows as do Wei and Wu (2002) in analyzing the determinants of bilateral FDI and bank lending.

We construct a similar variable called "distantness," which is the weighted average of the distances from the capital city of the particular country to the capital cities of the other countries, using the GDP shares of the other countries as weights. We construct this variable following KalemliOzcan, Sorensen, and Yosha (2003). We use Arcview software to obtain latitude and longitude of each capital city and calculate the great arc distance between each pair. The GDP weights capture the positive relation between trade volume and GDP. This variable is different than "distance from equator" and average distance so it is not a proxy for geography. It is a proxy for "remoteness," and hence captures information frictions. For example, a country like Congo, which is closer to the equator, is going to be farther from other countries if we just look at average distance. It is going to be even farther according to our measure because of the GDP weights. Based on our measure, a country like U.S. will be one of the least remote countries. ${ }^{30}$ Table 1 shows that the most disadvantaged country in terms of this variable is 3 times more distant then the least disadvantaged country. We expect the distantness variable to be negatively significant. Table 2 shows descriptive statistics for the additional control variables that are used in the robustness analysis.

\subsection{Correlations}

In table 3, we display the matrix of correlations between the regressors. In general, most of the correlations are all below 0.50, with the clear exception of GDP, institutions and schooling. Log GDP per capita and institutional quality are highly correlated in all three samples and so are log GDP per capita and log schooling. Since the main point of our analysis is to find out which of the explanatory variables remove the "Lucas Paradox," it is very important to look at the role of each variable one at a time and also in a multiple regression framework given the high correlations. We also undertake Monte Carlo simulations and other tests to show that our results are not spurious

\footnotetext{
${ }^{30}$ Denoting the distance from country $i$ 's capital city to country $j$ 's capital city by $d_{i j}$, country $i$ 's distantness is defined as $\frac{1}{T} \Sigma_{t=1}^{T} \Sigma_{j} d_{i j} g d p_{j}^{t} / g d p^{t}$ where $g d p^{t}$ is the year $t$ sample-wide (total) GDP, and $T$ is the sample length. For Congo: average distance (without the weights) is $6600 \mathrm{kms}$ (it ranks $35 \mathrm{th}$ in a sample of 60 , where 1 is the farthest) and distantness is $9000 \mathrm{kms}$ (it ranks 16th in a sample of 60, where 1 is the most distant). For U.S: average distance (without the weights) is $8700 \mathrm{kms}$ (it ranks 28 th in a sample of 60, where 1 is the farthest) and distantness is 6400 $\mathrm{kms}$ (it ranks 45 th in a sample of 60 , where 1 is the most distant).
} 
due to highly correlated variables. Table 4 shows the correlations between the main explanatory variables and the additional control variables that are used in the robustness analysis.

\subsection{OLS Regressions}

Specification and the Results

We perform cross-country OLS regressions. The main reason for this is that most of our explanatory variables are slowly changing over time. Figure 2 plots the evolution of each component of our composite institutional quality index, averaged for all 58 countries in our "base" sample for the KLSV data. It is clear that there is almost no time variation in the institutional quality index during our sample period. Figure 3 plots the evolution of each component only for the poor countries in the same sample, which are the developing and emerging market countries. We can easily see that the improvements in the indices of external conflict, internal conflict, government stability, and to some extent investment profile are all due to the improvements in the developing countries. ${ }^{31}$

Table 5 reports OLS regressions of average inflows of direct and portfolio equity investment per capita on log of GDP per capita in 1970 and average institutional quality, using the IMF, IFS capita flows data. The linear regressions are for the equation,

$$
F_{i}=\mu+\alpha \log Y_{i}+\beta I_{i}+\varepsilon_{i}
$$

where $F$ is average inflows of direct and portfolio equity investment per capita (inflows of capital per capita), $\mu$ is a constant, $Y_{i}$ is $\log$ of GDP per capita in 1970, $I_{i}$ is average institutional quality and $\varepsilon_{i}$ is a random error term. The coefficients of interest are both $\alpha$ and $\beta$, the effect of $\log$ GDP per capita and institutional quality on inflows of direct and portfolio equity investment per capita respectively.

We have 98 countries, denoted as the "whole world" sample, and 81 countries as the "base" sample. The "whole world" samples have similar descriptive statistics. ${ }^{32}$ Our additional explana-

\footnotetext{
${ }^{31}$ The improvement in the government stability and internal conflict components for developing countries during the 1990s captures the political changes in Latin America and Asia, in particular in Guatemala and El Salvador, where the civil wars were ended, and in India, where government stability improved after the violence in the 1980s.

${ }^{32}$ For the 98 country whole world sample out of the IMF data: mean and the standard deviation for the inflows are 103.9, and 158.4; mean and the standard deviation for the GDP per capita are 5.9, and 4.5; mean and the standard deviation for institutions are 6.8, and 1.4. For the 61 country "whole world" sample out of KLSV data: mean and the standard deviation for the inflows are 38.0, and 58.37; mean and the standard deviation for the GDP per capita are 5.12, and 4.02; mean and the standard deviation for institutions are 6.9, and 1.6. For the 60 country "whole
} 
tory variables are only available for the "base" sample. Both of these samples are composed of poor and rich, and small open and large open economies. ${ }^{33}$ Notice that since both capital inflows and log GDP are in per capita terms, we are already controlling for the size effects. Our main result is that institutional quality is the variable that explains the "Lucas Paradox." Column (1) demonstrates that capital flows to rich countries, the "Lucas Paradox." In column (2) we add our index of institutional quality. Upon this addition, we see that the "Lucas Paradox" disappears. The institutional quality is the "preferred" variable by the data. This result may not be surprising from an econometric standpoint since the recent research on institutions and development shows that these two variables are highly collinear because the historically determined component of institutions is a very good predictor for income in $1970 .{ }^{34}$ Nevertheless, our index of institutions is significant at $1 \%$ level, while the log GDP per capita is not. Columns (3) and (4) repeat the same exercise for the "base" sample. The impact of institutions on capital inflows in our "base" sample is quite similar to that of the "whole world" sample.

As shown in column (5), on its own the index of institutions can explain $52 \%$ of the crosscountry variation in inflows of direct and portfolio equity investment per capita. It is very striking that log GDP per capita has no additional explanatory power, which can be seen by comparing columns (4) and (5). The partial $\mathrm{R}^{2}$ is 0.0 for the $\log$ GDP per capita, whereas it is 0.13 for the index of institutions as seen by comparing columns (3) and (4).

To get a sense of the magnitude of the effect of institutional quality on inflows of direct and portfolio equity investment per capita, let's consider two countries such as Guyana and Italy: if we move up from the 25 percentile (Guyana) to the 75 percentile (Italy) in the distribution of the index of institutions, based on the results shown in column (4), we have 187.54 dollars more inflows per capita over the sample period on average. This represents a $60 \%$ increase in inflows per capita over the sample mean, which is 117.34 dollars, therefore it has quite an effect.

Table 6 investigates the role of the other proposed explanations for the "Lucas Paradox," both for the whole world and for the "base" samples. Notice that "whole world" sample changes for each variable due to data availability. In column (1), we add average log years of schooling, which turns out to be insignificant. ${ }^{35}$ In column (2), we add log distantness, which also turns out to

world" sample out of LM data: mean and the standard deviation for the inflows are 193.0, and 313.3; mean and the standard deviation for the GDP per capita are 6.7, and 5.3; mean and the standard deviation for institutions are 7.1, and 1.5.

${ }^{33}$ See appendix B for the detailed list of countries.

${ }^{34}$ A similar result can be find in Acemoglu et al. (2003), where they investigate the effect of institutional quality and GDP per capita on growth volatility.

${ }^{35}$ We repeat the analysis using average years of higher schooling instead of total schooling as the measure human capital and get similar results. 
be insignificant. Column (3) looks at the role of restrictions to capital mobility, which enters negative and significant at 1\% level. However, log GDP per capita also remains positive and significant and hence restrictions to capital mobility cannot account for the "Paradox." Columns (4)-(6) repeat the same exercise for the "base" sample, obtaining similar results. Column (7) runs the multiple regression, where the "Paradox" disappears because of the inclusion of the index of institutions. Only in the regressions where the index of institutions is included on its own (as shown in table 5) or together with the other explanatory variables, log GDP per capita becomes insignificant. Restrictions to capital mobility is also an important determinant but it cannot account for the "Paradox." The institutional quality variable is robust to inclusion of the other explanatory variables and is always significant at the $1 \%$ level. One might argue that PPP based GDP is higher in the poor countries that receive low levels of inflows, an issue which will cause a downward bias on log GDP per capita. Column (8) runs the same regression using log GDP per capita (constant 1996 dollars) in 1970 instead of the PPP based measure used in the previous columns and shows that this is not the case. The estimated coefficient on log GDP per capita is little higher but still insignificant and the estimated coefficient on institutional quality is very similar. ${ }^{36}$ The results are also economically significant as before. Based on the results shown in column (7), if we move up from the 25 percentile (Philippines) to the 75 percentile (Spain) in the distribution of the index of institutions we have 163.32 dollars more inflows per capita over the sample period on average. This represents a $40 \%$ increase in inflows per capita over the sample mean, which is 117.34 dollars.

Table 7 repeats the same exercise using KLSV capital inflows data. As mentioned, these data are better measures of capital flows. Column (1) demonstrates the "Lucas Paradox" for the "whole world" sample. Column (2) shows our main result that the "Lucas Paradox" disappears with the addition of institutional quality. Columns (3) and (4) demonstrate the same result for the "base" sample for which all of the main explanatory variables are available. As before, the estimated coefficients are very similar in both samples. Column (4) also shows a partial $R^{2}$ of 0.16 for the index of institutional quality. Columns (5)-(7) add the other proposed explanations for the "Paradox." Both log years of schooling and restrictions to capital mobility are significant at $1 \%$ level with the right sign. However log GDP per capita remains to be significant in these specifications, i.e., these other potential explanations cannot account for the "Paradox." As before, in the multiple regression of column (8) institutional quality is the main explanation for the capital inflows in the last thirty years and log GDP per capita becomes insignificant. Column (9) repeats column (8) using log GDP per capita (constant 1996 dollars) instead of the PPP log GDP per capita, obtaining

\footnotetext{
${ }^{36}$ We thank an anonymous referee for pointing this out.
} 
a similar result.

To get a sense of the magnitude of the effect of institutional quality on inflows of direct and portfolio equity investment, we will perform the following exercise: based on the results shown in column (4), if we move up from the 25 percentile (Syria) to the 75 percentile (U.K.) in the distribution of the index of institutions we have 77.30 dollars more inflows per capita over the sample period on average. This represents a $100 \%$ increase in inflows per capita over the sample mean, which is 38.57 dollars. Results shown in column (8) imply a $70 \%$ increase over the sample mean (an increase of 65.67 dollars). These results imply a significantly large effect of institutional quality on foreign investment.

Table 8 reports the result of the same specifications using the LM data, obtaining similar results.

Are the Results Driven by Multicollinearity?

One might worry that the results are spurious due to the high correlation between GDP per capita and institutions. Given the multiple regression framework we are capturing the direct effect of institutional quality on capital inflows. GDP per capita also depends on institutional quality, creating an indirect effect. Given the high correlation between them we may not be able to identify the individual effects. We undertake a number of tests to show that indeed we are capturing the independent effect of institutions and multicollinearity is not driving our results.

Panel A of the figure 4 plots the residuals from the regression of average inflows of direct and portfolio equity investment per capita on average institutional quality against the residuals from the regression of log GDP per capita in 1970 on average institutional quality. The Frisch-Waugh theorem says the coefficient from this regression is exactly the same as the one for GDP per capita in the multiple regression. Thus the slope of the fitted line is 0.14 as shown in column (4) of table 5. Similarly, Panel B of the same figure plots the residuals from the regression of average inflows of direct and portfolio equity investment per capita on log GDP per capita in 1970 against the residuals from the regression of institutions on log GDP per capita in 1970. By the Frish-Waugh theorem the slope of the fitted line is 0.75 as shown in column (4) of table $5 .^{37}$ It is clear from the figures that the exogenous component of log GDP per capita cannot explain the cross-country variation in capital inflows per capita but the exogenous component of the index of institutions can. What is also clear from the figures is that the strong positive relation between the institutional quality index

\footnotetext{
${ }^{37}$ The Frisch-Waugh theorem can be shown as follows: To establish the conditional correlation for the variable of interest, that is institutional quality, and given the main regression, $F_{i}=\mu+\alpha \log Y_{i}+\beta I_{i}+\varepsilon_{i}$, we run $I_{i}=$ $\lambda_{0}+\lambda_{1} \log Y_{i}+\epsilon_{i}$ and $F_{i}=\gamma_{0}+\gamma_{1} \log Y_{i}+\nu_{i}$, then we run $\nu_{i}=\zeta+\theta \epsilon_{i}+\omega$. By Frish-Waugh theorem $\theta=\beta$.
} 
and the capital inflows per capita is evidently not due to the specific outliers. Recently "opened up" economies like East Asian countries, for example, might be a group of outliers driving the results. It is clear from the figure that our results are not driven by capital account liberalization episodes but rather by countries, which, ceteris paribus, have very high levels of institutional quality, such as Denmark, Sweden, Netherlands, Norway, and U.K. Figure 5 repeats the same exercise for our "preferred" KLSV data "base" sample. The slopes of the fitted lines in panels A and B correspond to the coefficients in column (4) of table 7.

Another way to think about the above exercise is the following. It is clear that GDP per capita and the index of institutions have a common component and each can be written as a linear function of the other and an error term. We argue that the "variable-specific" component of the index of institutions - defined as the residual from the regression of average institutional quality on log GDP per capita in 1970 - has the explanatory power and the "variable-specific" component of GDP-defined as the residual from the regression of log GDP per capita in 1970 on average institutional quality-does not have any explanatory power. ${ }^{38}$

Appendix $\mathrm{C}$ reports results on three different simulation exercises, which are different regression diagnostic tests and are performed using the KLSV "base" sample of 58 countries. These are Monte Carlo simulations, perturbation exercise based on Beaton, Rubin, and Barone (1976), and calculating a condition index as in Belsley (1991). All of these show that our results are not spurious due to highly correlated variables. ${ }^{39}$ In addition none of our robustness regressions show any big sign and magnitude changes, which are typical indicators of multicollinearity.

\section{Institutions and the "Lucas Paradox:" IV Estimates}

It is possible that the capital inflows affect the institutional quality of a country. More inflows can generate incentives to reform and create an investor friendly environment. ${ }^{40}$ Moreover most institutional quality measures are constructed ex-post, and the analysts may have had a natural bias in "assigning" better institutions to countries with higher capital inflows. Another source

\footnotetext{
${ }^{38}$ Upon running a regression of average capital inflows per capita on average institutional quality and the "variablespecific component" of log GDP per capita in 1970, which is the residual from the regression of log GDP per capita in 1970 on average institutional quality we confirm that this independent component of log GDP per capita in 1970 has no effect. When we run a regression of average capital inflows per capita on log GDP per capita in 1970 and the "variable-specific" component of average institutional quality instead, which is the residual from the regression of average institutional quality on log GDP per capita in 1970, we find that the independent component of the index of institutions clearly has the explanatory power and this is exactly what drives our results. By the Frish-Waugh theorem, the coefficients on the "variable specific" components are the same as in the multiple regression.

${ }^{39}$ We thank to an anonymous referee for encouraging us to do these exercises, which strengthened our paper.

${ }^{40}$ See Rajan and Zingales (2003).
} 
of endogeneity can come from the possibility that both inflows and institutional quality might be determined by an omitted third factor. We believe the extensive robustness analysis that is undertaken in appendix D shows that this is not the case.

As a first cut, table 9 regresses average capital inflows over 1985-1997 on institutional quality in 1984 and log GDP per capita in 1984. There is a positive and significant effect of pre-sample institutions on the subsequent 13 years of capital inflows per capita. The coefficient that is reported in column (2) is higher than the one reported in column (4) of table 7 as expected. Institutional quality can account for the $59 \%$ of the variation. Log GDP per capita does not have any additional explanatory power, where the partial $R^{2}$ is 0.0 .

Our second approach is to run IV regressions using instruments that are not subject to reverse causality and can account for the institutional variation. La Porta, Lopez-de-Silanes, Shleifer, and Vishny $(1997,1998)$ emphasize the importance of the legal origins on the current institutions. They examine the laws governing investor protection, the enforcement of these laws, and the extent of concentration of firm ownership across countries. They find that countries with different legal histories offer different types of legal protection to their investors. Most countries' legal rules, either through colonialism, conquest, or outright borrowing, can be traced to one of four distinct European legal systems: English common law, French civil law, German civil law, and Scandinavian civil law. They show that countries whose legal rules originate in the common law tradition offer the greatest protection to investors. As far as law enforcement is concerned, German civil law and Scandinavian civil law countries emerge superior. The French civil law countries offer both the weakest legal protection and the worst enforcement. These legal origin variables have been increasingly adopted as exogenous determinants of institutional quality in the economic growth literature.

In contrast, Acemoglu, Johnson, and Robinson (2001, 2002) emphasize the conditions in the colonies. They argue that it is not the identity of the colonizer or the legal origin what matters, but whether the European colonialists could safely settle in a particular location. If the European settlement was discouraged by diseases or where the surplus extraction was beneficial via an urbanized and prosperous population, the Europeans set up worse institutions. Thus, they argue that historical mortality rates of European settlers are valid instruments for current institutions of former colonies. They also claim that the legal origin is a weak instrument for institutional quality, in particular for institutions that protect property rights. They claim it is hard to make a case that legal origins do not have any direct effect on the relevant outcome variables such as income levels. They stress that successful instruments have to be theoretically excludable from the empirical model 
used by the econometrician and undertaking overidentification tests are not enough. As a result we use log European settler mortality rates as an instrument for institutions, which is an excludable instrument as shown below.

Table 10 presents the results of the two stage least squares regressions in panel A, the associated first stage regressions in panel B, and the OLS counterpart in panel C. We only have 34 countries since only 34 out of our 58 country "base" sample are the former colonies where we have the $\log$ settler mortality data available. As shown in column (1) average institutional quality has a causal effect on average inflows of direct and portfolio equity investment per capita, where average institutional quality is instrumented by log European settler mortality. The first stage regression shows the significant effect of $\log$ settler mortality on institutional quality with an $R^{2}$ of $0.39 .{ }^{41}$ The estimated coefficient is higher than the OLS counterpart that is shown in panel C and also higher than the one reported in table 9 , since IV regression corrects both for endogeneity and the attenuation bias caused by the measurement error in the index of institutions. In fact, the results suggest that measurement error in the index of institutions is a more serious concern then reverse causality. Column (2) adds log GDP per capita in 1970 as an additional control. The qualitative results are the same. Of course the estimated coefficients are much higher here given the collinearity between log European settler mortality and log GDP per capita.

To get a sense of the magnitude of the effect of institutional quality on inflows of direct and portfolio equity investment, we will perform the following exercise: Based on the results shown in column (1), if we move up from the 25 percentile (Peru) to the 75 percentile (Australia) in the distribution of the index of institutions we have 78.58 dollars more inflows per capita over the sample period on average. This represents an almost 5 times increase in inflows per capita over the sample mean, which is 15.76 dollars. Given the causal effect these results imply an impressively large effect of institutional quality on foreign investment. Notice that the quantitative effect obtained from the IV regression is much larger than the one obtained from the OLS regression due to the attenuation bias in the OLS regression.

Table 11 reports the results of the tests for validity and excludability of the instrument, following Acemoglu, Johnson and Robinson (2001). Instrumenting average institutional quality with other instruments - British legal origin and English language - column (1) shows that log European settler mortality is excludable from the main regression. The overidentification tests also show that the instruments are valid. We use Hansen's overidentification test (J-test) to check the null hypothesis

\footnotetext{
${ }^{41}$ This is similar to the first stage regression in Acemoglu, Johnson and Robinson (2001), where they regress the average risk of expropriation (which is one the components of our index of institutions) on log settler mortality. Their estimated coefficient is $-0.61(0.13)$ with an $R^{2}$ of 0.27 .
} 
of whether the instruments for institutions we choose are valid. P-values for the overidentification test are reported in panel C. We cannot reject the hypothesis that our instruments are appropriate since all of p-values far exceed the conventional $5 \%$ significance level.

\section{Conclusion}

Our objective in this paper has been to analyze empirically the role of different theoretical explanations behind the lack of flows of capital from rich countries to poor ones. We undertake a systematic empirical study to evaluate the role of the alternative explanations behind the "Lucas Paradox," which include differences in fundamentals and capital market imperfections. Our empirical evidence shows that for the period 1970-2000, institutional quality is the leading causal variable explaining the "Lucas Paradox."

Our findings also generate implications for the patters of international flows during the last century. Obstfeld and Taylor (2004) characterize four different periods in terms of the "U-shaped" evolution of capital mobility. An upswing in capital mobility occurred from 1880 to 1914 during the Gold Standard period. Before 1914, capital movements were free and flows reached unprecedented levels. The international financial markets broke up during World War I. In the 1920s, policymakers around the world tried to reconstruct the international financial markets. Britain returned to the gold standard in 1925 and led the way to restoring the international gold standard for a short period. Capital mobility increased between 1925 and 1930. As the world economy collapsed into depression in the 1930s, so did the international capital markets. World War II was followed by a period of limited capital mobility. Capital flows began to increase starting in the 1960s, and further expanded in the 1970s after the demise of the Bretton Woods system. In terms of the "Lucas Paradox," Obstfeld and Taylor (2004) argue that capital was somewhat biased towards the rich countries in the first global capital market boom in pre-1914, but it is even more so today. If the "Lucas Paradox" characterized to a certain extent the pre-1914 global capital market, and if it persists today to the extent that poorer countries receive even less flows than during the pre-1914 boom, what is the explanation? We argue that it is differences in institutional quality among the poor and rich countries.

The "Lucas Paradox" has received a lot of attention as the different explanations behind the puzzle have different and sometimes opposite policy responses. Our results suggest that policies aimed at strengthening the protection of property rights, reducing corruption, increasing government stability, bureaucratic quality and law and order should be at the top of the list of policy makers seeking to increase capital inflows to poor countries. Recent studies emphasize the role of 
institutions in achieving higher levels of income, but they remain silent on the specific mechanisms. Our results indicate that foreign investment might be a channel through which institutions affect long-run development. 


\section{Appendices}

\section{A Data Descriptions and Sources}

Inflows of direct and portfolio equity investment per capita (IMF): 1970-2000. Data on inflows of direct and portfolio equity investment are from the IMF, International Financial Statistics (lines 78bed and 78bmd respectively). Inflows are expressed in constant 1996 U.S. dollars. Direct investment (line 78bed) includes equity capital, reinvested earnings, other capital and financial derivatives associated with various intercompany transactions between affiliated enterprises. Excluded are inflows of direct investment capital into the reporting economy for exceptional financing, such as debt-for-equity swaps. Equity liabilities (line 78bmd) include shares, stock participation, and similar documents that usually denote ownership of equity.

For conversion to per capita terms the mid-year total population is used.

Stocks of Foreign Capital (KLSV): 1970-1997. Foreign claims on domestic capital in 1990 constant U.S. dollars, from Kraay, Loayza, Serven, and Ventura (2000, 2005). The authors construct estimates of stocks of foreign capital using initial stocks and inflows of direct and portfolio investment and adjust the capital stock to reflect the effects of changes in market prices and exchange rates according to $S_{i t}=V_{i t} S_{i t-1}+F_{i t}$, where $S_{i t}$ denotes the initial stock of the asset in country $i$ at the end of period $t$ in constant 1990 U.S. dollars; $F_{i t}$ the inflow of new investment in constant 1990 U.S. dollars; and $V_{i t}$ the gross change between periods $t-1$ and $t$ in the value of the asset. The gross change in the value of the asset was calculated using $V_{i t}=(1-\delta) \frac{P_{t-1}}{P_{t}} \frac{e_{i t}}{e_{i t-1}} \frac{P_{i t}^{I}}{P_{i t-1}^{I}}$; where $\delta=0.06$ is the depreciation rate; $P_{t}$ is the U.S. price level; $e_{i t}$ is the exchange rate in local currency units per U.S. dollars; and $P^{I}$ is the investment deflator in country $i$ at time $t$. The authors argue that in principle, one would like the capital stock to be measured at market value. An obvious choice would be to proxy changes in the value of capital by changes in a share price index. The authors argue against this approach because capital listed on the stock market, especially in developing countries, is not representative of the stock of capital. Moreover, in thin markets, the link between changes in share prices and the underlying value of firms is tenuous. Thus, the authors consider replacement cost, and proxy changes in this by the change in the local currency investment deflator. Data on initial stocks were taken from the IMF, Balance of Payments Statistics and OECD's (1972) "Stocks of Private Direct Investment by DAC countries in Developing Countries End 1967." For countries for which no stock information is available, they infer initial stocks as the ratio of the flow of investment in that asset relative to the gross domestic investment, multiplied by the domestic capital stock. In order to smooth out year-to-year deviations, they use the average investment 
ratio in the first three years for which flow data is available. In most cases for portfolio equity investment, the observed initial flows are zero, and so this results in an estimate of a zero initial stock. Inflows data on direct investment and portfolio equity liabilities were taken from the IMF, IFS statistics.

Stocks of Foreign Capital (LM): 1970-1998. Foreign claims on domestic capital, from Lane and Milesi-Ferretti (2001). The authors construct estimates of stocks of equity and foreign direct investment using initial stock data and inflow data adjusted to reflect the effect of changes in market prices and exchange rates.

Stock measures of portfolio equity liabilities (EQL) are constructed based on cumulative equity inflows, taken from the IMF's IFS and BOPS. For equity inflows, Lane and Milesi-Ferretti adjust the stock outstanding at the end of year $t-1$ for changes in the value of the stock market in U.S. dollar terms between the end of the year $t-1$ and the end of the year $t$. The flows are assumed to occur uniformly during the year and thus their end of year value was calculated by multiplying them by the ratio of the stock market value in U.S. dollars at the end of the year $\left(\mathrm{p}^{*}\right)$ over its average during the year $(\bar{p} *)$. Hence, $E Q L_{t}=E Q L_{t-1} \frac{p *_{t}}{p *_{t-1}}+\Delta E Q L_{t} \frac{p *_{t}}{\overline{p *} t}$. Inflows data on portfolio equity liabilities were taken from the IMF, IFS statistics as described above. Stock measures are taken from the International Investment Position (IIP) data published by BOPS and IFS.

The stock value of foreign direct investment liabilities (FDIL) is obtained by cumulating the dollar amount of yearly inflows (including reinvested profits) adjusted for variations in the price of capital. Instead of assuming that FDI is in the form of investment in some standardized "machinery" whose price in dollar terms follows the price of capital in the U.S. (i.e. the price of capital goods increases at the same rate regardless of location), the authors assume that capital goods are closer to non-traded goods and that the relative price of investment goods across countries follows relative CPIs. These assumptions imply that the change in the domestic price of capital goods is the sum of the change in the relative price of capital between the country and the U.S. (the currency of denomination of flows), plus the increase in the U.S. price of capital; $F D I L_{t}=F D I L_{t-1} \frac{\text { rerus }_{t}}{\text { rerust }-1}\left(1+\pi_{t}^{k}\right)+\Delta F D I L_{t}$, where rerus is the country's real exchange rate vis-a-vis the US dollar, and an increase measures an appreciation; and $\pi^{k}$ is the rate of change of the price of capital in U.S. dollars. The estimates of stocks of FDI according to this methodology, however, can overstate the actual stock of FDI because a) write-offs of existing capital are not taken into account, ${ }^{42}$ and b) given accounting practices, in the presence of inflation, nominal depreciation allowances imply that part of reinvested profits are offsetting real capital depreciation and should

\footnotetext{
${ }^{42}$ Notice that the formula does not include a depreciation term or allowances for when a machine becomes obsolete.
} 
not be counted as capital. The inflation adjustment to the stock implies instead that each dollar of reinvested profits is calculated in "real" terms. In order to address these problems, the authors compute the measure of FDI capital based on the above formula but without any correction for inflation in capital goods' prices, $F D I L_{t}=F D I L_{t-1} \frac{\text { rerust }}{\text { rerust }-1}+\Delta F D I L_{t}$. Inflows data on direct investment were taken from the IMF, IFS statistics as described above. The initial values for stocks were taken from from the IMF, Balance of Payments Statistics, OECD's (1972) "Stocks of Private Direct Investment by DAC countries in Developing Countries End 1967" and Sinn (1990) "Net External Asset Position of 145 Countries: Estimation and Interpretation." When stocks were unavailable, the authors use cumulative inflows using data back to the 1950s.

The data in current U.S. dollars is converted into constant 1996 U.S. dollars by using the U.S. CPI in 1996.

Inflows of direct and portfolio equity investment per capita out of KLSV and LM stock data: These inflows are obtained by first differencing the stocks estimates of KLSV and LM. For conversion to per capita terms, the mid-year total population is used.

Population: 1970-2000. Total population from from World Bank, World Development Indicators (2004).

Consumer price index (CPI): U.S. CPI with base year $1996=1$ is from World Bank, World Development Indicators (2004).

GDP per capita in 1970 in PPP 1996 U.S. dollars: Gross Domestic Product in purchasing power parity 1996 U.S. dollars, from Alan Heston, Robert Summers and Bettina Aten, Penn World Table (PWT) Version 6.1, Center for International Comparisons at the University of Pennsylvania (CICUP), October 2002.

GDP per capita in 1970 in constant U.S. dollars: Gross domestic product from World Bank, World Development Indicators (2004). We adjust the base years by using U.S. CPI, depending on the base year of the inflows (1990 for the KLSV data and 1996 for the IMF and LM data).

Institutional Quality: 1984-2000. This is a composite index, which is the sum of all yearly rating components from International Country Risk Guide, The PRS Group. The index is re-scaled to range from 0 to 10, where a higher score means lower risk. Composite index contains the following sub-components:

- Government Stability. The government's ability to carry out its declared program(s), and its ability to stay in office. Average yearly rating from 0 to 12, where a higher score means lower risk.

- Investment Profile. This is an assessment of factors affecting the risk to investment that are not covered by other political, economic and financial risk components. It is the sum of three 
subcomponents, each with a maximum score of 4 points and a minimum score of 0 points. A score of 4 points equates to Very Low Risk and a score of 0 points to Very High Risk. The subcomponents are: Contract Viability/Expropriation, Profits Repatriation, Payment Delays.

- Internal Conflict. Political violence in the country and its actual or potential impact on governance. Average yearly rating from 0 to 12 , where a higher score means lower risk.

- External Conflict. Assessment both of the risk to the incumbent government from foreign action, ranging from non-violent external pressure (diplomatic pressures, withholding of aid, trade restrictions, territorial disputes, sanctions, etc.) to violent external pressure (crossborder conflicts to all-out war). Average yearly rating from 0 to 12 , where a higher score means lower risk.

- Non-corruption Index. Assessment of corruption within the political system. Average yearly rating from 0 to 6 , where a higher score means lower risk.

- Non-militarized Politics. Protection from the military involvement in politics. Average yearly rating from 0 to 6 , where a higher score means lower risk.

- Protection from Religious Tensions. Protection from the religious tensions in society. Average yearly rating from 0 to 6 , where a higher score means lower risk.

- Law and Order. The Law sub-component is an assessment of the strength and impartiality of the legal system; the Order sub-component is an assessment of popular observance of the law. Average yearly rating from 0 to 6 , where a higher score means lower risk.

- Protection from Ethnic Tensions. Assessment of the degree of tension within a country attributable to racial, nationality, or language divisions. Average yearly rating from 0 to 12, where a higher score means lower risk.

- Democratic Accountability. Average yearly rating from 0 to 6 , where a higher score means lower risk. In general, the highest number of risk points is assigned to alternating democracies, while the lowest number of risk points is assigned to authoritarian regimes.

- Quality of Bureaucracy. Institutional strength and quality of the bureaucracy is another shock absorber that tends to minimize revisions of policy when governments change. Average yearly rating from 0 to 4 , where a higher score means lower risk.

Years of Schooling: 1970, 1975, 1980, 1985, 1990, 1995, 1999. Average years of secondary, higher and total schooling in the total population. Data from Barro, Robert J. and Jong-Wha Lee (2000), International Data on Educational Attainment: Updates and Implications. Center for International Development at Harvard University (CID).

Distantness: 1970-2000. Variable constructed as the weighted average of the distances in thousands of kms from the capital city of the particular country to the capital cities of the other countries, 
using the total GDP shares of the other countries as weights, averages across a particular time period. In symbols: denoting the distance from country $i$ 's capital city to country $j$ 's capital city by $d_{i j}$, country $i$ 's distantness is defined as $\frac{1}{T} \Sigma_{t=1}^{T} \Sigma_{j} d_{i j} g d p_{j}^{t} / g d p^{t}$ where $g d p^{t}$ is the year $t$ group-wide (total) GDP, and $T$ is the sample length. Pair-wise distance is taken from Arcview 3.x software. Restrictions to Capital Mobility: 1971-2000, The mean value of four dummy variables: 1) Exchange Arrangements: separate exchange rates for some or all capital transactions and/or some or all invisibles; 2) Payments restrictions on payments for current transactions; 3) Payments restrictions on payments for capital transactions; 4) Surrender or Repatriation Requirements for Export Proceeds. From International Monetary Fund, Annual Report on Exchange Arrangements and Exchange Restrictions.

\section{Additional controls used in the robustness analysis:}

Inflation Volatility: 1970-1997. The standard deviation of annual Consumer Price Index (CPI) percentage change divided by the average of the annual inflation over the particular time period, from World Bank, World Development Indicators (2004).

Corporate Tax Rate: 1997. Corporate tax rates from KPMGs Corporate Tax Rates Survey available at http://www.us.kpmg.com/microsite/global_tax/ctr_survey/.

Trade Openness: 1971-1997. Sum of exports and imports of goods and services measured as a share of GDP from World Bank, World Development Indicators (2004).

FDI Incentives: 1990-1997. Index on incentives to FDI, constructed by Wei (2000). Wei (2000) converts the textual information in the $\mathrm{PwC}$ reports on FDI incentives into numerical codes. For the measurement of incentives, a variable was created based on the presence or absence of restrictions in: 1) existence of special incentives for foreigners to invest in certain industries or certain geographic areas; 2) tax concessions specific to foreign firms (including tax holidays and tax rebates, but excluding concessions for export promotion); 3) non-tax concessions such as tax grants, subsidized loans and reduced rent; 4) special promotion for exports.

FDI Restrictions: 1990-1997. Index on restrictions to FDI constructed by Wei (2000). Wei (2000) converts the textual information in the $\mathrm{PwC}$ reports into numerical codes. For the measurement of restrictions, a variable was created based on the presence or absence of restrictions in: 1) exchange controls; 2) exclusion of foreign firms from certain strategic sectors (in particular, national defense and the mass media); 3) exclusion of foreign firms from other sectors where their presence would be considered harmless in most developed countries; 4) restriction on the share of foreign ownership. 
The overall restriction index is the sum of these variables.

Paved Roads: 1990-1997. The percent of paved roads in total. Paved roads are those surfaced with crushed stone (macadam) and hydrocarbon binder, with concrete or with cobblestones. Data from World Bank, World Development Indicators (2004).

Bank Assets: 1970-1997. Claims on domestic real nonfinancial sector by deposit money banks as a share of GDP from Beck, Demirguc-Kunt, Levine, (2005), A New Database on Financial Development and Structure.

Stock Market Value Traded: 1970-1997. Total shares traded on the stock market exchange as a share of GDP from Beck, Demirguc-Kunt, Levine, (2005), A New Database on Financial Development and Structure.

Total Factor Productivity (TFP): 1970-1997. TFP is estimated as Solow residual from the neoclassical production function, $y=A k^{\alpha}$, as $y / k^{\alpha}$ where $y$ is GDP per capita, $k$ is domestic capital stock per capita, and $\alpha=0.3$.

Capital Stock per capita in 1970: Domestic capital stock including gold reserves per capita in 1970 expressed in constant 1990 U.S. dollars, from Kraay, Loayza, Serven, and Ventura (2000) taken from Summers and Heston Penn World Tables Version 5.6. For conversion to per capita terms the mid-year total population is used.

Oil Dummy: A dummy for the major oil-exporting countries. Included are Organization of Petroleum Exporting Countries (OPEC) members (Algeria, Indonesia, Iran, Iraq, Kuwait, Libya, Nigeria, Qatar, Saudi Arabia, the United Arab Emirates, and Venezuela) as well as Bahrain, Ecuador, Gabon, and Oman.

Malaria: 1994. The proportion of a country's population at risk of falciparum malaria transmission from Arthur, John W. and Jeffrey D. Sachs, (2000).

Sovereign Risk Moody's: 1990-1997. An index based on Moody's sovereign ratings (foreign currency, country ceiling for bonds and notes). Index numbers recoded from letter scores from 1 (AAA, lowest risk) to 24 ( $\mathrm{C}$, highest risk).

Sovereign Risk SEYP: 1990-1997. An index based on Standard\&Poor's long term foreign currency denominated sovereign debt ratings. Index numbers recoded from letter scores from 1 (AAA, lowest risk) to 23 (Serial Default, highest risk).

Reuters: 1987-2000. Number of times a country is mentioned in Reuters. Source is Reuters database from Doug Bond, Joe Bond, Churl Oh, (2001), Integrated Data for Events Analysis (IDEA) project, Harvard University.

Foreign Bank Asset Share: 1990-1997. The share of foreign bank assets in total banking sector 
assets from Beck, Demirguc-Kunt, Levine, (2005), A New Database on Financial Development and Structure. Original data are from IBCA's BankScope database. A foreign bank is defined as foreign if at least $50 \%$ of the equity is owned by foreigners.

Legal origin: Origin of formal legal code in the country: English common-law, French civil law, German civil law, and Scandinavian civil law from La Porta, Lopez-de-Silanes, Shleifer, and Vishny (1997, 1998).

English Language: Fraction of the population speaking English as a mother tongue, from Hall and Jones (1999).

European settlers' mortality: Historical European settlers' mortality rates from Acemoglu, Johnson, and Robinson (2001). Mortality rates are measured in terms of deaths per annum per 1000 "mean strength" (raw mortality numbers are adjusted to what they would be if a force of 1000 living people were kept in place for a whole year, e.g., it is possible for this number to exceed 1000 in episodes of extreme mortality as those who die are replaced with new arrivals). 


\section{B Samples}

\section{"Whole World" Sample. IMF Flows Data (98 Countries)}

Albania (ALB), Algeria (DZA), Angola (AGO), Argentina (ARG), Armenia (ARM), Australia (AUS), Austria (AUT), Azerbaijan (AZE), Bangladesh (BGD), Belarus (BLR), Bolivia (BOL), Brazil (BRA), Bulgaria (BGR), Burkina Faso (BFA), Cameroon (CMR), Canada (CAN), Chile (CHL), Colombia (COL), Congo (COG), Costa Rica (CRI), Cote d'Ivore (CIV), Croatia (HRV), Cyprus (CYP), Czech Rep. (CZE), Denmark (DNK), Dominican Rep. (DOM), Ecuador (ECU), Egypt (EGY), El Salvador (SLV), Estonia (EST), Ethiopia (ETH), Finland (FIN), France (FRA), Gabon (GAB), Gambia (GMB), Germany (DEU), Ghana (GHA), Greece (GRC), Guatemala (GTM), Guinea (GIN), Guyana (GUY), Haiti (HTI), Honduras (HND), Hungary (HUN), India (IND), Indonesia (IDN), Iran (IRN), Israel (ISR), Italy (ITA), Jamaica (JAM), Japan (JPN), Jordan (JOR), Kazakhstan (KAZ), Kenya (KEN), Korea (KOR), Latvia (LVA), Lithuania (LTU), Madagascar (MDG), Malaysia (MYS), Mali (MLI), Mexico (MEX), Morocco (MAR), Mozambique (MOZ), Namibia (NAM), Netherlands (NLD), New Zealand (NZL), Nicaragua (NIC), Niger (NER), Nigeria (NGA), Norway (NOR), Oman (OMN), Pakistan (PAK), Panama (PAN), Papua New Guinea (PNG), Paraguay (PRY), Peru (PER), Philippines (PHL), Portugal (PRT), Russia (RUS), Saudi Arabia (SAU), Senegal (SEN), Sierra Leone (SLE), Singapore (SGP), Slovenia (SVN), South Africa (ZAF), Spain (ESP), Sweden (SWE), Trinidad and Tobago (TTO), Tunisia (TUN), Turkey (TUR), Uganda (UGA), Ukraine (UKR), United Kingdom (GBR), United States (USA), Uruguay (URY), Vietnam (VNM), Zambia (ZMB), Zimbabwe (ZWE).

\section{"Base" Sample. IMF Flows Data (81 Countries)}

All from corresponding "whole world" sample except for Albania (ALB), Algeria (DZA), Angola (AGO), Armenia (ARM), Azerbaijan (AZE), Burkina Faso (BFA), Cote d'Ivore (CIV), Ethiopia (ETH), Gabon (GAB), Guinea (GIN), Kazakhstan (KAZ), Madagascar (MDG), Namibia (NAM), Nigeria (NGA), Oman $(\mathrm{OMN})$, Saudi Arabia (SAU), Vietnam (VNM).

\section{"Whole World" Sample. KLSV Flows Data (61 Countries)}

Algeria (DZA), Australia (AUS), Austria (AUT), Bangladesh (BGD), Bolivia (BOL), Brazil (BRA), Cameroon (CMR), Canada (CAN), Chile (CHL), China (CHN), Colombia (COL), Congo (COG), Costa Rica (CRI), Cote d'Ivore (CIV), Denmark (DNK), Dominican Rep. (DOM), Ecuador (ECU), Egypt (EGY), El Salvador (SLV), Finland (FIN), France (FRA), Germany (DEU), Greece (GRC), Guatemala (GTM), Honduras (HND), India (IND), Indonesia (IDN), Iran (IRN), Ireland (IRL), Israel (ISR), Italy (ITA), Jamaica (JAM), Japan (JPN), Jordan (JOR), Korea (KOR), Malaysia (MYS), Mexico (MEX), Morocco (MAR), Netherlands (NLD), New Zealand (NZL), Nicaragua (NIC), Norway (NOR), Oman (OMN), Pakistan (PAK), Peru (PER), Philippines (PHL), Portugal (PRT), Senegal (SEN), South Africa (ZAF), Spain (ESP), Sri Lanka (LKA), Sweden (SWE), Syria8 (SYR), Thailand (THA), Trinidad and Tobago (TTO), Tunisia (TUN), Turkey (TUR), United Kingdom (GBR), United States (USA), Uruguay (URY), Venezuela (VEN). 


\section{"Base" Sample. KLSV Flows Data (58 Countries)}

All from corresponding "whole world" sample except for Algeria (DZA), Cote d'Ivore (CIV), Oman (OMN).

\section{"Base" Sample for IV. KLSV Flows Data (34 Countries)}

Australia (AUS), Bangladesh (BGD), Bolivia (BOL), Brazil (BRA), Cameroon (CMR), Canada (CAN), Chile (CHL), Colombia (COL), Congo (COG), Costa Rica (CRI), Dominican Rep. (DOM), Ecuador (ECU), Egypt (EGY), El Salvador (SLV), Guatemala (GTM), Honduras (HND), India (IND), Indonesia (IDN), Jamaica (JAM), Malaysia (MYS), Mexico (MEX), Morocco (MAR), New Zealand (NZL), Nicaragua (NIC), Pakistan (PAK), Peru (PER), Senegal (SEN), South Africa (ZAF), Sri Lanka (LKA), Trinidad and Tobago (TTO), Tunisia (TUN), United States (USA), Uruguay (URY), and Venezuela (VEN).

\section{"Whole World" Sample. LM Flows Data (60 Countries)}

Algeria (DZA), Argentina (ARG), Australia (AUS), Austria (AUT), Bolivia (BOL), Botswana (BWA), Brazil (BRA), Canada (CAN), Chile (CHL), China (CHN), Colombia (COL), Costa Rica (CRI), Cote d'Ivore (CIV), Denmark (DNK), Dominican Rep. (DOM), Ecuador (ECU), Egypt (EGY), El Salvador (SLV), Finland (FIN), France (FRA), Germany (DEU), Guatemala (GTM), India (IND), Indonesia (IDN), Israel (ISR), Italy (ITA), Jamaica (JAM), Japan (JPN), Jordan (JOR), Korea (KOR), Kuwait (KWT), Malaysia (MYS), Mexico (MEX), Morocco (MAR), Netherlands (NLD), New Zealand (NZL), Norway (NOR), Oman (OMN), Pakistan (PAK), Panama (PAN), Paraguay (PRY), Peru (PER), Philippines (PHL), Portugal (PRT), Saudi Arabia (SAU), Singapore (SGP), South Africa (ZAF), Spain (ESP), Sri Lanka (LKA), Sweden (SWE), Syria8 (SYR), Thailand (THA), Trinidad and Tobago (TTO), Tunisia (TUN), Turkey (TUR), United Kingdom (GBR), United States (USA), Uruguay (URY), Venezuela (VEN), Zimbabwe (ZWE).

\section{"Base" Sample. LM Flows Data (56 Countries)}

All from corresponding "whole world" sample except for Algeria (DZA), Cote d'Ivore (CIV), Morocco (MAR), Oman $(\mathrm{OMN})$. 


\section{Regression Diagnostics}

We performed a series of tests and simulation exercises in order to show that our results are not spurious due to the high correlation between GDP per capita and institutional quality variables. The tests are performed using the KLSV "base" sample of 58 countries.

\section{C.1 Monte Carlo Exercise}

We first take the two key explanatory variables: log of GDP per capita PPP in 1970 (log GDP per capita) and average institutional quality, 1984-1997 (institutions). We generate a random sample for each variable, where the size is equal to our actual sample and where the means, standard deviations and correlations correspond to those of the actual data of 58 countries as shown in table 1 and table 3. The mean and standard deviation for the institutions variable are, respectively, 6.9 and 1.6. The mean and standard deviation for the log of GPD per capita are, respectively, 8.2 and 0.8. The correlation between log of GDP per capita and institutions is 0.84 .

We then generate an artificial dependent variable, $\tilde{F}$, average inflows of capital per capita, by calculating,

$$
\tilde{F}_{i}=\mu^{\prime}+\alpha^{\prime} \log \tilde{Y}_{i}+\beta^{\prime} \tilde{I}_{i}+\tilde{\varepsilon_{i}}
$$

where $\mu^{\prime}$ is a constant, $\tilde{Y}_{i}$ is the randomly generated $\log$ of GDP per capita, $\tilde{I}_{i}$ is the randomly generated institutional quality and $\tilde{\varepsilon_{i}}$ is a random error term. The constant was chosen so that the randomly generated dependent variable would end up having roughly the same value as the dependent variable in table 7 . This assumption, however, is immaterial for the results. The coefficients on log GDP per capita and institutions were chosen to be equal to 2.0. The error term $\tilde{\varepsilon}$ 's standard deviation was chosen to be that of the inflows per capita variable in table 1 .

We then regress $\tilde{F}_{i}$ on $\tilde{Y}_{i}$ and $\tilde{I}_{i}$ using OLS. This exercise is repeated 500 times. Panels A and $\mathrm{B}$ in table $\mathrm{C}-1$ show the randomly generated data to have the same characteristics as the original data. Panel $\mathrm{C}$ presents the properties of the estimated coefficients using the randomly generated data. The average value of log GDP per capita across the 500 regressions is 2.3 , close to the value of 2 . The average value of institutions, 2.1 , is also close to its true value of 2 . In this exercise, only in 31 out of 500 cases $(6 \%)$, we fail to reject the hypothesis that the coefficient on log GDP per capita is equal to 0.0 but we do reject the hypothesis that the coefficient on institutions is 0.0 . So only $6 \%$ of the time our inference is that institutions matter and GDP per capita does not, even though the exercise assumes both of them matter equally. 
We repeated the exercise incorporating randomly generated values for the other right hand side variables, such as, log years of schooling, and log distantness. The coefficients for years of schooling and $\log$ distantness were chosen to reflect the estimated values seen in table 7 , hence, we chose 0.0 for both of them. We obtained similar results. In this case, we find that in 29 out of 500 cases $(5.8 \%)$, we fail to reject the hypothesis that the coefficient on log GDP per capita is equal to 0.0 but we do reject the hypothesis the coefficient on institutions is 0.0 .

These results suggest that our results are not spurious due to the highly correlated variables.

\section{C.2 Perturbation Exercise}

We performed another numerical exercise following Beaton, Rubin, and Barone (1976). We create a random sample (perturbed data) by adding an error term to the original (unperturbed) data. We then analyzed whether these perturbed data of possible exact values of the original data yield similar results to the ones obtained from the original unperturbed data.

We take the main variables, log GDP per capita PPP in 1970 (log GDP per capita) and average institutional quality (institutions). Beaton, Rubin, and Barone (1976) generate a plausible set of the independent variables by adding a rectangular (uniformly) distributed random number $E$ between -0.5 and +0.499 in the digit after the last published digit. The new perturbed data are then exactly the same as the published set if rounded to the published number of digits.

In the regression analysis, we use the log of GDP per capita, instead of the original published non-log data. Hence, we first first round the log of GDP per capita to one decimal point. We then add a rectangular distributed random number between -0.5 and +.499 in the digit after the first (rounded) decimal point. Also, given that our index of institutions is an average over the sample period, in principle we can obtain more than one decimal point for the original data. We first round our institutional quality indicator to the first decimal point and then add a uniform distributed random number between -0.5 and +0.499 in the digit after the first (rounded) decimal point. Following Beaton, Rubin and Barone (1976), we ignore all errors in the dependent variable.

We run a regression with these "perturbed" data on the right hand side and store the values of the coefficients.

$$
F_{i}=\mu^{\prime \prime}+\alpha^{\prime \prime} \log \left(Y_{i}+E\right)+\beta^{\prime \prime}\left(I_{i}+E\right)+\varepsilon_{i}^{\prime \prime}
$$

where $E$ denotes the added rounding error term. We repeated this exercise 1000 times. Table 
C-2 presents the unperturbed (original) solution. ${ }^{43}$ We then show the mean, median and standard deviation of the "perturbed" coefficients. We also present the lowest and highest value. The "percentage agreement" is the percentage of the perturbed coefficients that agree with the unperturbed solution to at least one digit. ${ }^{44}$ We also show the result of the test of equal means. We cannot reject the null hypothesis that the unperturbed solution is the average of all solutions for these equally likely data sets. We show the $P_{l i m}$ value and the t-test that the $P_{l i m}$ value equals the unperturbed solution. ${ }^{45}$ Figure C-1 shows the Monte Carlo distribution of "perturbed" coefficients. We repeated the exercise using all the main right hand side variables and got similar results. Overall our results are robust to adding a perturbation error.

\section{C.3 Conditioning Index}

As shown by Belsley (1991), one can calculate a condition index as a mean for determining when there are collinear relations among the columns of a data matrix $\mathbf{X}$. The condition index equals to the square root of the largest eigenvalue divided by the smallest eigenvalue. When there is no collinearity at all, the eigenvalues and the condition index will all be equal to 1 . As collinearity increases, eigenvalues will be both greater and smaller than 1 , where eigenvalues close to zero indicating a multicollinearity problem, thus condition index will increase. Belsley shows that if the condition index is bigger than 15 then multicollinearity is a concern and if it is greater than 30 it is a very serious concern.

We calculate the condition indices for the regression shown in column (4) of table 5 and column (4) of table 7. The indices are 14.6 and 12.6 respectively, indicating that multicollinearity is not a concern for our results.

\footnotetext{
${ }^{43}$ The difference between the values of table C-2 and table 7 are due to the fact that in this exercise we rounded the data to one decimal point.

${ }^{44}$ Let $\mathrm{U}$ be the unperturbed solution and $\mathrm{P}$ be a perturbed solution; then $\mathrm{P}$ is said to agree with $\mathrm{U}$ if $\mathrm{P}$ falls within the interval U+-five units in the second significant digit of $\mathrm{U}$.

${ }^{45}$ The $P_{\text {lim }}$ can be thought as the center of the distribution of the perturbed coefficients assuming a large sample size.
} 


\section{Robustness Checks}

One source of endogeneity can come from the possibility that both inflows and institutional quality might be determined by an omitted third factor. We believe the extensive robustness analysis undertaken in this section shows this not to be the case.

Table D-1 shows the results of adding extra control variables. Some of our robustness variables are available for only the 1990s; therefore corresponding regressions are only for the 1990s. Column (1) investigates the role of log average inflation volatility, which captures average macroeconomic instability. This variable turns out to be insignificant. Because the lack of flows can be due to heavy taxation, we also add corporate income tax as another policy variable. As shown in column (2), our results are robust to the inclusion of this variable. ${ }^{46}$ Institutional quality remains positive and significant. Another variable that might play a role is trade. ${ }^{47}$ As shown in column (3), our results are robust to the inclusion of average trade openness defined as the sum of exports and imports as a share of output. The institutional quality variable remains highly significant. Trade, however, has no effect. ${ }^{48}$ Columns (4) and (5), respectively, test for the effects of restrictions and incentives to FDI. The restriction index is the sum of four dummies for exchange controls, exclusion of foreign firms from certain strategic sectors, exclusion of foreign firms from other non-strategic sectors, and restriction on the share of foreign ownership. ${ }^{49}$ The incentive index is a dummy for incentives for foreigners to invest in specific industries or geographic areas. ${ }^{50}$ Only the incentive index enter significantly. The role of institutional quality, on the other hand, remains positive and significant. As seen in column (6), the results are robust to using variables that proxy government infrastructure. We use the percentage of paved roads in total roads, averaged over the sample period, as a measure of infrastructure. Because of complementarities between public and private capital, the former can be considered another potential omitted factor of production that affects the productive opportunities in an economy. The effect of this variable is positive, but not significant. We also

\footnotetext{
${ }^{46}$ This variables is available for the 1990 s only. In addition, the significance of this variable is not robust to our other samples. Hence we decided not to include it as a main explanatory variable.

${ }^{47}$ Mundell (1957) shows commodity movements and factor movements to be substitutes. Markusen (1983) and Svensson (1984) show that, whether trade and factor mobility are complements or substitutes, depends on the assumptions made with respect to factor intensities, technology, and preferences.

${ }^{48}$ Lane (2004) finds a positive association between trade openness and the level of external debt. He argues that this result supports theories of constrained access to international credit markets.

${ }^{49}$ Since this variable includes a capital controls component, we also use this index without our restrictions to capital mobility variable, obtaining similar results.

${ }^{50}$ We also used the other incentive variables, namely tax concessions, non-tax concessions, special promotion for exports and got similar results. These indices were coded by Wei (2000) following a detailed description compiled by PriceWaterhouseCoopers. Corporate tax rate is also from Wei. Unfortunately these variables are available only for one year, where that year changes between 1990-1997 from country to country. Hence we decided not to include them among the main explanatory variables.
} 
use financial market development as another variable that represents good domestic fundamentals. In theory, higher levels of financial development lead to higher productivity of capital. ${ }^{51}$ We try several standard measures of credit market development, namely liquid liabilities of the financial system, total credit to private sector, and credit by deposit money banks to private sector (all as shares of GDP, averaged over the sample period). We report the result with bank credit in column (7). We also try measures of capital market development. We use stock market capitalization (shown in column (8)) and total value traded on the stock market (as shares of GDP, averaged over the sample period). Both turn out to be insignificant. Inclusion of these measures together with the credit market variables and/or on their own did not change the overall picture.

Table D-2 looks at some other indicators. As explained before, it is hard to separate the effects of the incentive structure (institutions) on the adoption of new technologies from the TFP itself. Hence it may be the case that our institutional quality variable is a proxy for TFP differences. However, we do not have a good measure that captures international TFP differences given the fact that technology can be transferred and imitated. Hence the empirical literature on growth tends to calculate TFP measures as a residual of growth rates minus factor accumulation weighted by their relative contribution to production. We also construct a similar proxy variable for TFP by solving for $A$ in equation (1) and assuming the value of $\alpha=1 / 3$. We also calculate TFP growth rates calculated as the growth rate of per capita output minus one third of the growth rate of the per capita capital stock. We calculate both of these variables for every year and every country in our sample period. As seen in column (1), average level of TFP growth has an insignificant effect. The results with the TFP growth rate are the same. If we use these variables alone both turn out to be positive and significant. Our institutional quality variable remains positive and significant. We repeat the analysis using capital stock per capita instead of GDP per capita as a measure of the "Lucas Paradox" as shown in column (2). Neoclassical theory suggests that capital will flow from the capital abundant country to the capital scarce country. From another point of view, this exercise also can be viewed as evidence for the presence of externalities in the localization of production; capital goes where capital is. We use the 1970 value of the domestic capital stock per capita since this will be the relevant value for the future inflows. As shown in column (2) of table D-2, the results are very similar. Institutional quality remains the main explanation for the "Lucas Paradox." If capital stock is used on its own it turns out to be positive and significant. We also

\footnotetext{
${ }^{51}$ Note that financial market development can also be considered a measure of asymmetric information as it mitigates information problems. In a standard frictionless general equilibrium model a la Arrow-Debreu financial intermediaries are redundant. Information asymmetries or transaction costs are required to justify the existence of financial intermediaries.
} 
used an oil country dummy, a Sub-Saharan country dummy and existence of Malaria, all of which turns out to be insignificant.

We also experiment with some other variables for fundamentals. For example, we use land because it can be another potential omitted factor of production such as human capital and hence countries with less land may have low marginal productivity of capital. This variable turns out to be insignificant and thus we do not report the results. We also use ratio of external debt to GDP, which turns out to be insignificant, and hence not reported. Our capital control measure is an average of four dummy variables as explained before. We try two of these measures on their own: restrictions on payments for capital transactions and surrender or repatriation requirements for export proceeds. The results are qualitatively the same and therefore not reported.

The institutional quality variable is a composite index of the various components. We use each component of this index independently to see which ones are driving the result. Government stability, internal conflict, non-corruption, law and order, democratic accountability, bureaucratic quality, and investment profile seem to be important determinants of capital inflows. Other components such as external conflict, non-militarized politics, and protection from religious tensions turn out to be insignificant. We do not report these results for the space considerations. ${ }^{52}$

In table D-3, to test the robustness of the results obtained using the distantness variable as a measure of asymmetric information, we try several other measures for asymmetric information. First as shown in columns (1) and (2), we use the sovereign debt ratings, from Standard and Poor's (S\&P), and Moody's as a measure of sovereign risk. These data reflect the assessment of each government's capacity and willingness to repay debt according to its terms. S\&P's appraisal of each sovereign's creditworthiness is based on economic and financial performance and political factors. They observe that "willingness to repay is a qualitative issue that distinguishes sovereigns from most other types of issuers. Partly because creditors have only limited redress, a government can (and does) default selectively on its obligations, even when it possesses the financial capacity for timely debt service." Thus, although this measure is highly correlated with the ICRG variables, their objective and methodology are quite different. In order to eliminate any possible perception bias, ICRG does not use any outside expert opinion, such as influential investors who might have assets in the rated country. $\mathrm{S} \& \mathrm{P}$, on the other hand, relies on this from time to time. These variables turn out to be negative but not significant. ${ }^{53}$ Our institutional quality variable is robust to the

\footnotetext{
${ }^{52}$ The results are reported in the working paper version: Harvard Business School Working Paper Series, No. 05-054, 2004.

${ }^{53}$ Most emerging markets do not have a sovereign rating before the early 1990 s. Hence we run this regression for the 1990s decade only.
} 
inclusion of the sovereign risk variable. In column (3) we use a variable called Reuters. This variable is the number of times the country is mentioned in Reuters. This measure should potentially reflect the international business community's awareness about the country that they are investing in. The sign is positive, but the coefficient is not significant. Then we try foreign banks (share of foreign banks with at least $50 \%$ of foreign capital in total banks) and accounting practices (an index for the degree of transparency in accounting) as alternative measures of asymmetric information. Both enter with correct signs but are not significant. We also tried accounting practices from Wei (2000) and get similar results. ${ }^{54}$ Of course all these measures are endogenous and hence distantness is our "preferred" measure. Finally we use distantness as weighted by population instead of GDP. The results are the same as before.

Table D-4 reports the results of our main regressions using data on total capital inflows, including debt from the Lane and Milessi-Feretti (LM) data set. Columns (1) and (2) repeat the results from column (2) and (8) of table 8. Column (3) and (4) adds debt inflows to the inflows of direct and portfolio equity investment making the left hand side total inflows of capital per capita. The results are similar.

Table D-5 repeats the analysis for the decades in our sample period. Institutional quality remains the main explanation for the "Lucas Paradox" for the different decades and subperiods, as shown in columns (1) to (7). We conjecture that the lower significance of the institutional quality variable during the 1980s can be accounted by the general cutoff of lending in the international capital markets following Mexico's announcement to halt foreign interest payments on August 15, 1982, which marked the beginning of the international debt crisis. ${ }^{55}$ Notice that the ICRG data, hence our composite institutional quality index starts in 1984. As shown in figures 2and 3, our composite index does not change much over our sample period. Thus we use the average value of the index for the 1970s and 1980s.

\footnotetext{
${ }^{54}$ The results are reported in the working paper version: Harvard Business School Working Paper Series, No. 05-054, 2004.

${ }^{55}$ As Eichengreen and Lindert (1989) observe, during the 1980s private creditors tended to withhold capital from potential borrowers in all developing countries, not just the conspicuous problem debtor countries.
} 


\section{References}

Acemoglu, Daron, Simon Johnson and James A. Robinson (2001), "The Colonial Origins of Comparative Development: An Empirical Investigation," American Economic Review 91, 1369 1401.

Acemoglu, Daron, Simon Johnson and James A. Robinson (2002), "Reversal of Fortune: Geography and Institutions in the Making of the Modern World Income Distribution," The Quarterly Journal of Economics 117, 1231-1294.

Acemoglu, Daron, Simon Johnson, James Robinson and Yunyong Thaicharoen (2003), "Institutional Causes, Macroeconomic Symptoms: Volatility, Crises and Growth," Journal of Monetary Economics 50, 49-123.

Alfaro, Laura, Sebnem Kalemli-Ozcan and Vadym Volosovych (2004), "Why Doesn't Capital Flow from Rich to Poor Countries? An Empirical Investigation," Harvard Business School Working Paper Series 05-054.

Arthur, John W. and Jeffrey D. Sachs (2000), "Institution and Geography: Comment on Acemoglu, Johnson, and Robison (2000)," NBER Working Paper, 8114. National Bureau of Economic Research, Cambridge.

The Bankers Almanac (2001), BANKbase, CD-ROM. Windsor Court East Grinstead House, United Kingdom.

Barro, Robert J. and Jong-Wha Lee (2000), "International Data on Educational Attainment: Updates and Implications," The Center for International Development at Harvard University Working Paper No. 42.

Beaton, Albert. E, Donald B. Rubin, and John L. Barone (1976), "The Acceptability of Regression Solutions: Another Look at Computation Accuracy," Journal of the American Statistical Association 71, 158-168.

Beck, Thorsten, Asli Demirguc-Kunt, and Ross Levine (2005), "A New Database on Financial Development and Structure," World Bank Economic Review 14, 597-605.

Belsley, David, A. (1991), Conditioning Diagnostics: Collinearity and Weak Data in Regression, John Wiley and Sons, New York.

Bond, Doug, Joe Bond and Churl Oh (2001), "Integrated Data for Events Analysis (IDEA): An Event Topology for Automated Events Data Development," mimeo.

Champion, Marc and Juliane von Reppert-Bismarck (2005), "Talking Turkey Pays Dividends; Mere Start of EU Negotiations is Enough to Encourage Investors," Wall Street Journal, October 5,18

Calvo, Guillermo, Leonardo Leiderman and Carmen Reinhart (1996), "Inflows of Capital to Developing Countries in the 1990s," The Journal of Economic Perspectives 10, 123-139. 
Coval, Joshua and Tobias J. Moskowitz (1999), "Home Bias at Home: Local Equity Preferences in Domestic Portfolios," Journal of Finance 54, 2045-2073.

Coval, Joshua and Tobias J. Moskowitz (2001), "The Geography of Investment: Informed Trading and Asset Prices," Journal of Political Economy 109, 811-841.

Clemens, Michael and Jeffrey G. Williamson (2004), "Wealth Bias in the First Global Capital Market Boom, 1870-1913," Economic Journal 114, 304-337.

Doidge, Craig, G. Andrew Karolyi, and Rene M. Stulz (2004), "Why Do Countries Matter so Much for Corporate Governance?" NBER Working Paper, 10726. National Bureau of Economic Research, Cambridge.

Edwards, Sebastian (1991), "Capital Flows, Foreign Direct Investment, and Debt-Equity Swaps in Developing Countries," in Capital Flows in the World Economy, Horst Siebert, editor. J.C.B. Mohr, Tubingen.

Eichengreen, Barry (2003), Capital Flows and Crisis. The MIT Press, Cambridge.

Eichengreen, Barry and Peter H. Lindert (1989), "Overview," in The International Debt Crisis in Historical Perspective, Barry Eichengreen and Peter H. Lindert, editors. The MIT Press, Cambridge.

Gertler, Mark and Kenneth Rogoff (1990), "North-South Lending and Endogeneous Domestic Capital Market Inefficiencies," Journal of Monetary Economics 26, 245-266.

Gomme, Paul (1993), "Money and Growth Revisited: Measuring the Costs of Inflation in an Endogenous Growth Model," Journal of Monetary Economics 32, 51-77.

Gordon, Roger H. and A. Lans Bovenberg (1996), "Why is Capital so Immobile Internationally? Possible Explanations and Implications for Capital Income Taxation?" American Economic Review 86, 1057-1075.

Hall, Robert E. and Charles Jones (1999), "Why Do Some Countries Produce So Much More Output per Worker than Others?" The Quarterly Journal of Economics 114, 83-116.

Helpman, Elhanan (2004), The Mystery of Economic Growth. Harvard University Press, Cambridge.

Henry, Peter B. and Peter L. Lorentzen (2003), "Domestic Capital Market Reform and Access to Global Finance: Making Markets Work," NBER Working Paper, 10064. National Bureau of Economic Research, Cambridge.

Heston, Alan, Robert Summers and Bettina Aten (2002), "Penn World Table Version 6.1," Center for International Comparisons at the University of Pennsylvania (CICUP).

International Monetary Fund (2001), International Financial Statistics, CD-ROM. The International Monetary Fund, Washington, DC.

International Monetary Fund, Annual Report on Exchange Arrangements and Exchange Restrictions, issues from 1970 to 1997. International Monetary Fund, Washington, D.C. 
Kalemli-Ozcan, Sebnem, Bent Sorensen and Oved Yosha (2003), "Risk Sharing and Industrial Specialization: Regional and International Evidence," American Economic Review 93, 903-918.

Kalemli-Ozcan, Sebnem, Ariell Reshef, Bent Sorensen and Oved Yosha (2003), "What Determines Capital Income Flows and Ownership Across U.S. States?" mimeo.

King, Robert and Rebelo Sergio (1993), "Transitional Dynamics and Economic Growth in the Neoclassical Model," American Economic Review 83, 908-931.

Klein, Michael (2005), "Capital Account Liberalization, Institutional Quality and Economic Growth: Theory and Evidence," NBER Working Paper 11112. National Bureau of Economic Research, Cambridge.

Kraay, Aart, Norman Loayza, Luis Serven and Jaume Ventura (2000), "Country Portfolios," NBER Working Paper, 7795. National Bureau of Economic Research, Cambridge.

Kraay, Aart, Norman Loayza, Luis Serven and Jaume Ventura (2005), "Country Portfolios," Journal of the European Association 3, 914-045.

La Porta, Rafael, Florencio Lopez-de-Silanes, Andrei Shleifer and Robert Vishny (1997), "Legal Determinants of External Finance," Journal of Finance 52, 1131-1150.

La Porta, Rafael, Florencio Lopez-de-Silanes, Andrei Shleifer and Robert Vishny (1998), "Law and Finance," Journal of Political Economy 106, 1113-1155.

Lane, Philip (2004), "Empirical Perspectives on Long-Term External Debt," Topics in Macroeconomics 4, 1-21.

Lane, Philip and Gian Maria Milesi-Ferretti (1999), "The External Wealth of Nations: Measures of Foreign Assets and Liabilities for Industrial and Developing Countries," IMF Working Paper 99/115. International Monetary Fund, Washington, D.C.

Lane, Philip and Gian Maria Milesi-Ferretti (2001), "The External Wealth of Nations: Measures of Foreign Assets and Liabilities for Industrial and Developing Countries," Journal of International Economics 55, 263-294.

Larrain, Felipe, Luis Lopez-Calva and Andres Rodriguez-Clare (2000), "Intel: A Case Study of Foreign Direct Investment in Central America," Center for International Development, Harvard University Working Paper 58.

Lucas, Robert E. (1990), "Why doesn't Capital Flow from Rich to Poor Countries?" American Economic Review 80, 92-96.

Markusen, James R. (1983), "Factor Movements and Commodity Trade as Complements," Journal of International Economics 14, 314-356.

Moody's Investors Service (2005), Sovereign Ratings History, Sovereign Risk Unit, Moody's Investors Service, New York.

Mundell, Robert (1957), "International Trade and Factor Mobility," American Economic Review $47,321-335$. 
North, Douglass C. (1981), Structure and Change in Economic History. Norton, New York.

North, Douglass C. (1994), "Economic Performance Through Time," American Economic Review 84, 359-368.

North, Douglass C. (1995), "Institutions," Journal of Economic Perspective 5, 97-112.

Obstfeld, Maurice (1995), "International Capital Mobility in the 1990s," in Understanding Interdependence. The Macroeconomics of the Open Economy, Peter Kenen, editor. Princeton University Press, Princeton.

Obstfeld, Maurice (2004), "External Adjustment," Bernhard Harms Lecture delivered at the Kiel Institute for World Economics.

Obstfeld, Maurice and Kenneth Rogoff (1995), Foundations of International Macroeconomics. The MIT Press, Cambridge.

Obstfeld, Maurice and Kenneth Rogoff (2000), "The Six Major Puzzles in International Macroeconomics: Is There a Common Cause?" in NBER Macroeconomics Annual 2000, Ben Bernanke and Kenneth Rogoff, editors. The MIT Press, Cambridge.

Obstfeld, Maurice and Alan M. Taylor (2004), Global Capital Markets Integration, Crisis, and Growth. Cambridge University Press, Cambridge.

O'Rourke, Kevin H. and Jeffrey G. Williamson (1999), Globalization and History: The Evolution of a Nineteenth-Century Atlantic Economy. The MIT Press, Cambridge.

Parente L. Stephen and Edward C. Prescott (2000), Barriers to Riches. The MIT Press, Cambridge.

The Political Risk Sevices Group (2001), International Country Risk Guide. The PRS Group, New York.

Portes, Richard and Helene Rey (2005), "The Determinants of Cross-Border Equity Transaction Flows," Journal of International Economics 65, 269-296.

Prescott, Edward (1998), "Needed: A Theory of Total Factor Productivity," International Economic Review 39, 525-552.

Rajan, Raghuram G. and Luigi Zingales (2003), "The Great Reversals: The Politics of Financial Development in the 20th Century," Journal of Financial Economics 69, 5-50.

Razin, Assaf and Chi-Wa Yuen (1994), "Convergence in Growth Rates: a Quantitative Assessment of the Role of Capital Mobility and International Taxation," in Capital Mobility: The Impact on Consumption, Investment, and Growth, Leonardo Leiderman and Assaf Razin, editors. Cambridge University Press, New York.

Reinhart, Carmen and Kenneth Rogoff (2004), "Serial Default and the "Paradox" of Rich to Poor Capital Flows," American Economic Review Papers and Proceedings 94, 52-58. 
Spar, Debora (1998), "Attracting High Technology Investment: Intel's Costa Rica Plant," World Bank Occasional Paper 11. World Bank, Washington, D.C.

Standard\&Poor's, Sovereign Credit Ratings, collected from the site www.standardandpoors.com. Standard \& Poor's, New York.

Svensson, Lars E.O. (1984), "Factor Trade and Goods Trade," Journal of International Economics $16,365-378$.

Stulz, Rene M. (2005), "The Limits of Financial Globalization," Journal of Finance 60, 1595-638.

Tornell, Aaron and Andres Velasco (1992), "Why Does Capital Flow from Poor to Rich Countries? The Tragedy of the Commons and Economic Growth," Journal of Political Economy 100, $1208-1231$.

Wei, Shang-Jin (2000), "Local Corruption and Global Capital Flows," Brookings Papers in Economic Activity 2, 303-346.

Wei, Shang-Jin and Yi Wu (2002), "Negative Alchemy? Corruption, Composition of Capital Flows, and Currency Crises," in Preventing Currency Crises in Emerging Markets, Sebastian Edwards and Jeffrey A. Frankel, editors. The University of Chicago Press, Chicago.

World Bank (2004), World Development Indicators, CD-ROM. The World Bank, Washington, DC. 
Table 1: Descriptive Statistics

\begin{tabular}{|c|c|c|c|c|}
\hline & Mean & Std.Dev. & Min & Max \\
\hline \multicolumn{5}{|c|}{ IMF, IFS Capital Flows Data: Base Sample of 81 Countries } \\
\hline $\begin{array}{l}\text { Average Inflows of Capital per capita, } 1970-2000 \\
\text { GDP per capita in } 1970 \text { (PPP 1996) } \\
\text { Average Institutional Quality, 1984-2000 } \\
\text { Average Years of Schooling, 1970-2000 } \\
\text { Average Distantness, } 1970-2000 \\
\text { Average Restrictions to Capital Mobility, 1970-2000 }\end{array}$ & $\begin{array}{r}117.34 \\
5.86 \\
6.94 \\
5.53 \\
7.93 \\
0.52\end{array}$ & $\begin{array}{r}170.29 \\
4.53 \\
1.50 \\
2.92 \\
2.11 \\
0.27\end{array}$ & $\begin{array}{r}-0.29 \\
0.61 \\
4.31 \\
0.48 \\
5.45 \\
0.00\end{array}$ & $\begin{array}{r}722.72 \\
16.49 \\
9.69 \\
11.41 \\
13.75 \\
0.97\end{array}$ \\
\hline \multicolumn{5}{|c|}{ KLSV Capital Flows Data: Base Sample of 58 Countries } \\
\hline $\begin{array}{l}\text { Average Inflows of Capital per capita, 1970-1997 } \\
\text { GDP per capita in 1970 (PPP 1990) } \\
\text { Average Institutional Quality, 1984-1997 } \\
\text { Average Years of Schooling, 1970-1997 } \\
\text { Average Distantness, 1970-1997 } \\
\text { Average Restrictions to Capital Mobility, 1970-1997 }\end{array}$ & $\begin{array}{r}38.57 \\
5.17 \\
6.92 \\
5.59 \\
8.16 \\
0.54\end{array}$ & $\begin{array}{r}59.27 \\
4.07 \\
1.64 \\
2.60 \\
1.96 \\
0.27\end{array}$ & $\begin{array}{r}-29.32 \\
0.85 \\
4.35 \\
1.78 \\
5.75 \\
0.00\end{array}$ & $\begin{array}{r}181.16 \\
15.74 \\
9.65 \\
11.41 \\
13.50 \\
1.00\end{array}$ \\
\hline \multicolumn{5}{|c|}{ LM Capital Flows Data: Base Sample of 56 Countries } \\
\hline $\begin{array}{l}\text { Average Inflows of Capital per capita, 1970-1998 } \\
\text { GDP per capita in 1970 (PPP 1996) } \\
\text { Average Institutional Quality, 1984-1998 } \\
\text { Average Years of Schooling, 1970-1998 } \\
\text { Average Distantness, 1970-1998 } \\
\text { Average Restrictions to Capital Mobility, 1970-1998 }\end{array}$ & $\begin{array}{r}202.29 \\
6.60 \\
7.12 \\
5.83 \\
8.28 \\
0.51 \\
\end{array}$ & $\begin{array}{l}322 \\
5.25 \\
1.52 \\
2.44 \\
2.20 \\
0.29\end{array}$ & $\begin{array}{l}0.80 \\
0.56 \\
4.46 \\
2.00 \\
5.43 \\
0.00\end{array}$ & $\begin{array}{r}1309.30 \\
23.39 \\
9.67 \\
11.41 \\
13.80 \\
0.98\end{array}$ \\
\hline
\end{tabular}

Notes: Average inflows of capital per capita, 1970-2000 include inflows of direct and portfolio equity investment from the IMF, IFS. The "base" sample is composed of 81 countries for which all the main explanatory variables are available. Inflows are expressed in constant 1996 U.S. dollars. Average inflows of capital per capita, 1970-1997 are the flows of foreign claims on domestic capital in constant 1990 U.S. dollars, from KLSV data set. The "base" sample is composed of 58 countries for which all the main explanatory variables are available. Average inflows of capital per capita, 1970-1998 are the flows of foreign claims on domestic capital in constant 1996 U.S. dollars, from LM data set. The "base" sample is composed of 56 countries for which all the main explanatory variables are available. GDP per capita in 1970 is the gross domestic product divided by population in 1970 in PPP basis (in 1990 U.S. dollars or 1996 U.S. dollars). Average institutional quality is the sum of all the rating components from International Country Risk Guide, averaged over the relevant sample period. The components are investment profile, government stability, internal conflict, external conflict, no-corruption index, non-militarized politics, protection from religious tensions, law and order, protection from ethnic tensions, democratic accountability, quality of bureaucracy. The index ranges from 0 to 10, where a higher score means lower risk. Average years of schooling is years of total schooling in total population, averaged over the relevant sample period. Average distantness is constructed as the weighted average of the distances in thousands of kms from the capital city of the particular country to the capital cities of the other countries, using the total GDP shares of the other countries as weights, averaged over the relevant time period. Average restrictions to capital mobility is the mean value of four dummy variables, averaged over the relevant sample period: 1) Exchange arrangements: separate exchange rates for some or all capital transactions; 2) Payments restrictions on payments for current transactions; 3) Payments restrictions on payments for capital transactions; 4) Surrender or repatriation requirements for export proceeds. See appendix A for detailed explanations of all the variables and sources. 
Table 2: Descriptive Statistics for the Additional Control Variables

\begin{tabular}{|c|c|c|c|c|c|}
\hline \multicolumn{6}{|c|}{ KLSV Capital Flows Data: Base Sample of 58 Countries } \\
\hline & Sample & Mean & Std.Dev & Min & Max \\
\hline Average Inflation Volatility, 1970-1997 & 58 & 0.86 & 0.69 & 0.27 & 4.41 \\
\hline Corporate Tax Rate in $1997^{a}$ & 44 & 33.98 & 7.30 & 15.00 & 53.20 \\
\hline Average FDI Restrictions, $1990-1997^{b}$ & 35 & 1.49 & 0.85 & 0.00 & 3.00 \\
\hline Average FDI Incentives, $1990-1997^{b}$ & 35 & 1.74 & 0.70 & 0.00 & 3.00 \\
\hline Average Trade Openness, 1970-1997 & 58 & 55.38 & 24.68 & 14.83 & 122.28 \\
\hline Average Paved Roads, $1990-1997^{c}$ & 57 & 53.72 & 32.21 & 4.79 & 100.00 \\
\hline Average Bank Assets, 1970-1997 & 58 & 0.44 & 0.25 & 0.07 & 1.08 \\
\hline Average Stock Market Value Traded, $1970-1997^{d}$ & 50 & 0.09 & 0.10 & 0.00 & 0.46 \\
\hline Average TFP, 1970-1997 & 58 & 0.37 & 0.18 & 0.14 & 0.78 \\
\hline Capital Stock per capita in 1970 & 58 & 11.11 & 12.21 & 0.73 & 55.15 \\
\hline Malaria in 1994 & 58 & 0.12 & 0.26 & 0.00 & 1.00 \\
\hline Average Sovereign Risk Moody's, $1990-1997^{f}$ & 38 & 6.49 & 4.50 & 1.00 & 14.25 \\
\hline Average Sovereign Risk S\&P, $1990-1997^{g}$ & 37 & 6.11 & 4.66 & 1.00 & 14.00 \\
\hline Average Reuters, 1987-1997 & 58 & 3.69 & 10.76 & 0.05 & 79.75 \\
\hline Average Foreign Banks Asset Share, $1990-1997^{h}$ & 49 & 0.12 & 0.12 & 0.00 & 0.42 \\
\hline
\end{tabular}

Notes: See appendix A for the detailed explanations of the variables. Samples: 58 is the "base" sample from the KLSV data set. ${ }^{a} 44$-country sample due to missing data on corporate tax rates. ${ }^{b} 35$-country sample due to missing data on FDI restrictions and incentives. ${ }^{c} 57$-country sample due to missing data on paved roads for CHN. ${ }^{d} 50$-country sample due to missing data on stock market value traded. ${ }^{f} 38$-country sample due to missing data on Moody's sovereign ratings. ${ }^{g} 37$-country sample due to missing data on S\&P's sovereign ratings. ${ }^{h} 49$-country sample due to missing data on foreign banks assets. 
Table 3: Correlation Matrix for the Main Explanatory Variables

IMF, IFS Capital Flows Data: Base Sample of 81 Countries

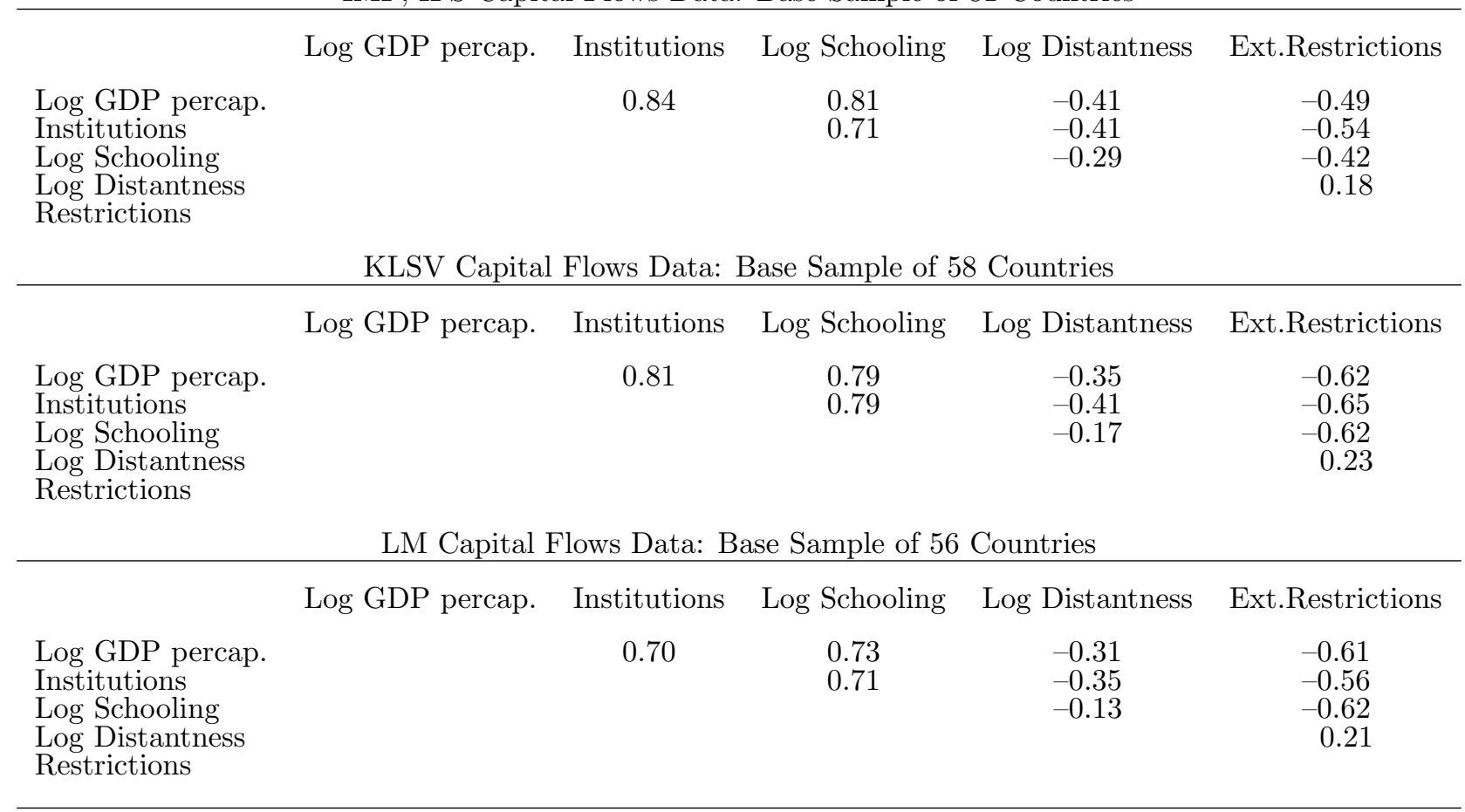

Notes: Log GDP per capita is the gross domestic product divided by population in 1970 in PPP basis (in 1990 U.S. dollars or 1996 U.S. dollars). Institutions is the sum of all the rating components from International Country Risk Guide, averaged over the relevant sample period. The components are investment profile, government stability, internal conflict, external conflict, no-corruption index, non-militarized politics, protection from religious tensions, law and order, protection from ethnic tensions, democratic accountability, quality of bureaucracy. The index ranges from 0 to 10, where a higher score means lower risk. Log schooling is years of total schooling in total population, averaged over the relevant sample period. Log distantness is constructed as the weighted average of the distances in thousands of kms from the capital city of the particular country to the capital cities of the other countries, using the total GDP shares of the other countries as weights, averaged over the relevant time period. Restrictions is the restrictions to capital mobility, which is the mean value of four dummy variables, averaged over the relevant sample period: 1) Exchange arrangements: separate exchange rates for some or all capital transactions; 2) Payments restrictions on payments for current transactions; 3) Payments restrictions on payments for capital transactions; 4) Surrender or repatriation requirements for export proceeds. See appendix A for detailed explanations of all the variables and sources. 
Table 4: Correlations between the Main and the Additional Control Variables

\begin{tabular}{|c|c|c|c|c|c|}
\hline & \multicolumn{5}{|c|}{ KLSV Capital Flows Data: Base Sample of 58 Countries } \\
\hline & Log GDP percap. & Institutions & Log Schooling & Log Distantness & Ext.Restrictions \\
\hline Log Inflation Volatility & -0.13 & -0.23 & -0.07 & 0.31 & 0.02 \\
\hline Corporate Tax Rate ${ }^{a}$ & 0.28 & 0.25 & 0.15 & -0.40 & -0.35 \\
\hline FDI Restrictions ${ }^{b}$ & -0.51 & -0.31 & -0.40 & 0.09 & 0.38 \\
\hline FDI Incentives ${ }^{b}$ & -0.40 & -0.53 & -0.39 & 0.05 & 0.43 \\
\hline Log Trade Openness & 0.02 & 0.08 & 0.10 & -0.20 & -0.13 \\
\hline Paved Roads ${ }^{c}$ & 0.45 & 0.56 & 0.47 & -0.62 & -0.41 \\
\hline Log Bank Assets & 0.50 & 0.67 & 0.54 & -0.52 & -0.47 \\
\hline Log Stock Market $^{d}$ & 0.37 & 0.53 & 0.54 & -0.34 & -0.37 \\
\hline Log TFP & 0.95 & 0.83 & 0.81 & -0.42 & -0.63 \\
\hline Log Capital Stock percap. & 0.95 & 0.86 & 0.82 & -0.34 & -0.62 \\
\hline Oil Dummy & -0.05 & -0.14 & -0.14 & 0.15 & -0.03 \\
\hline Malaria & -0.49 & -0.38 & -0.45 & 0.23 & -0.12 \\
\hline Sovereign Risk Moody's $f$ & -0.69 & -0.85 & -0.75 & 0.48 & 0.68 \\
\hline Sovereign Risk S\&P $\mathrm{P}^{g}$ & -0.76 & -0.88 & -0.77 & 0.47 & 0.73 \\
\hline Log Reuters & 0.41 & 0.45 & 0.50 & -0.28 & -0.38 \\
\hline Foreign Banks Assets ${ }^{h}$ & -0.38 & -0.47 & -0.38 & 0.22 & 0.14 \\
\hline
\end{tabular}

Notes: See appendix A for detailed explanations of these variables and sources. ${ }^{a} 44$-country sample due to missing data on corporate tax rates. ${ }^{b} 35$-country sample due to missing data on FDI restrictions and incentives. ${ }^{c} 57$-country sample due to missing data on paved roads for $\mathrm{CHN}$. ${ }^{d} 50$-country sample due to missing data on stock market value traded. ${ }^{f} 38$-country sample due to missing data on Moody's sovereign ratings. ${ }^{g} 37$-country sample due to missing data on S\&P's sovereign ratings. ${ }^{h} 49$-country sample due to missing data on foreign banks assets. 
Table 5: OLS Regressions of Capital Inflows per capita I - IMF Flows Data Dependent Variable is Average Capital Inflows per capita, 1970-2000

\begin{tabular}{|c|c|c|c|c|c|}
\hline & $\begin{array}{c}\text { Whole } \\
\text { World } \\
(1)\end{array}$ & $\begin{array}{c}\text { Whole } \\
\text { World } \\
(2)\end{array}$ & $\begin{array}{c}\text { Base } \\
\text { Sample } \\
(3)\end{array}$ & $\begin{array}{c}\text { Base } \\
\text { Sample } \\
(4)\end{array}$ & $\begin{array}{c}\text { Base } \\
\text { Sample } \\
(5)\end{array}$ \\
\hline Log GDP per capita (PPP) in 1970 & $\begin{array}{c}1.05^{* * *} \\
(0.17)\end{array}$ & $\begin{array}{c}0.20 \\
(0.13)\end{array}$ & $\begin{array}{c}1.18^{* * *} \\
(0.19)\end{array}$ & $\begin{array}{c}0.14 \\
(0.20)\end{array}$ & \\
\hline $\begin{array}{l}\text { Average Institutional Quality, } \\
\text { 1984-2000 }\end{array}$ & & $\begin{array}{c}0.68^{* * *} \\
(0.14)\end{array}$ & & $\begin{array}{c}0.75 * * * \\
(0.16)\end{array}$ & $\begin{array}{c}0.82^{* * *} \\
(0.12)\end{array}$ \\
\hline $\begin{array}{l}R^{2} \\
\text { Countries }\end{array}$ & $\begin{array}{c}0.37 \\
98\end{array}$ & $\begin{array}{c}0.52 \\
98\end{array}$ & $\begin{array}{c}0.39 \\
81\end{array}$ & $\begin{array}{c}0.52 \\
81\end{array}$ & $\begin{array}{c}0.52 \\
81\end{array}$ \\
\hline
\end{tabular}

Notes: All regressions include a constant and are estimated by OLS with White's correction of heteroscedasticity. Standard errors are in parentheses denoting *** $1 \%, * * 5 \%, * 10 \%$ significance. Samples: 98-country "whole world" sample includes all the countries with data available for inflows of capital, GDP per capita, and institutional quality, excluding outliers and countries with population less than a million. The "base" sample is composed of 81 countries for which all the main explanatory variables are available. Average inflows of capital per capita, 1970-2000 include inflows of direct and portfolio equity investment from the IMF, IFS. Inflows are expressed in constant 1996 U.S. dollars. GDP per capita in 1970 is the gross domestic product divided by population in 1970 in PPP basis (in 1996 U.S. dollars). Average institutional quality is the sum of all the rating components from International Country Risk Guide, averaged over the relevant sample period. The components are investment profile, government stability, internal conflict, external conflict, no-corruption index, non-militarized politics, protection from religious tensions, law and order, protection from ethnic tensions, democratic accountability, quality of bureaucracy. The index ranges from 0 to 10, where a higher score means lower risk. See appendix A for detailed explanations of all the variables and sources. 
Table 6: OLS Regressions of Capital Inflows per capita II- IMF Flows Data

Dependent Variable is Average Capital Inflows per capita, 1970-2000

\begin{tabular}{|c|c|c|c|c|c|c|c|c|}
\hline & $\begin{array}{l}\text { Whole } \\
\text { World } \\
(1)\end{array}$ & $\begin{array}{c}\text { Whole } \\
\text { World } \\
(2)\end{array}$ & $\begin{array}{c}\text { Whole } \\
\text { World } \\
(3)\end{array}$ & $\begin{array}{c}\text { Base } \\
\text { Sample } \\
(4)\end{array}$ & $\begin{array}{c}\text { Base } \\
\text { Sample } \\
(5)\end{array}$ & $\begin{array}{c}\text { Base } \\
\text { Sample } \\
(6)\end{array}$ & $\begin{array}{c}\text { Base } \\
\text { Sample } \\
(7)\end{array}$ & $\begin{array}{c}\text { Base } \\
\text { Sample } \\
(8)\end{array}$ \\
\hline $\begin{array}{l}\text { Log GDP per capita } \\
(\mathrm{PPP}) \text { in } 1970\end{array}$ & $\begin{array}{c}1.03^{* * *} \\
(0.22)\end{array}$ & $\begin{array}{c}0.99^{* * *} \\
(0.17)\end{array}$ & $\begin{array}{c}0.82^{* * *} \\
(0.14)\end{array}$ & $\begin{array}{c}1.14^{* * *} \\
(0.24)\end{array}$ & $\begin{array}{c}1.11 * * * \\
(0.19)\end{array}$ & $\begin{array}{c}0.91^{* * *} \\
(0.16)\end{array}$ & $\begin{array}{c}0.13 \\
(0.18)\end{array}$ & \\
\hline $\begin{array}{l}\text { Log GDP per capita } \\
(1996 \$) \text { in } 1970\end{array}$ & & & & & & & & $\begin{array}{c}0.20 \\
(0.15)\end{array}$ \\
\hline $\begin{array}{l}\text { Average Institutional } \\
\text { Quality, 1984-2000 }\end{array}$ & & & & & & & $\begin{array}{c}0.65^{* * *} \\
(0.15)\end{array}$ & $\begin{array}{c}0.59^{* * * *} \\
(0.14)\end{array}$ \\
\hline $\begin{array}{l}\text { Log Average Years of } \\
\text { Schooling, 1970-2000 }\end{array}$ & $\begin{array}{c}0.12 \\
(0.16)\end{array}$ & & & $\begin{array}{c}0.06 \\
(0.18)\end{array}$ & & & $\begin{array}{l}-0.10 \\
(0.15)\end{array}$ & $\begin{array}{l}-0.18 \\
(0.19)\end{array}$ \\
\hline $\begin{array}{l}\text { Log Average Distantness, } \\
1970-2000\end{array}$ & & $\begin{array}{l}-0.68 \\
(0.69)\end{array}$ & & & $\begin{array}{l}-0.58 \\
(0.72)\end{array}$ & & $\begin{array}{l}-0.29 \\
(0.58)\end{array}$ & $\begin{array}{l}-0.31 \\
(0.60)\end{array}$ \\
\hline $\begin{array}{l}\text { Average Restrictions to } \\
\text { Capital Mobility, } 1970-2000\end{array}$ & & & $\begin{array}{l}-1.54^{* * *} \\
(0.53)\end{array}$ & & & $\begin{array}{l}-1.83^{* * *} \\
(0.60)\end{array}$ & $\begin{array}{l}-1.23^{* * *} \\
(0.46)\end{array}$ & $\begin{array}{l}-1.17^{* * *} \\
(0.44)\end{array}$ \\
\hline $\begin{array}{l}R^{2} \\
\text { Countries }\end{array}$ & $\begin{array}{c}0.39 \\
92\end{array}$ & $\begin{array}{c}0.38 \\
98\end{array}$ & $\begin{array}{c}0.42 \\
97\end{array}$ & $\begin{array}{c}0.39 \\
81\end{array}$ & $\begin{array}{c}0.40 \\
81\end{array}$ & $\begin{array}{c}0.45 \\
81\end{array}$ & $\begin{array}{c}0.55 \\
81\end{array}$ & $\begin{array}{c}0.55 \\
81\end{array}$ \\
\hline
\end{tabular}

Notes: All regressions include a constant and are estimated by OLS with White's correction of heteroscedasticity. Standard errors are in parentheses denoting *** $1 \%, * * 5 \%, * 10 \%$ significance. Samples: 98-country "whole world" sample includes all countries with data available for inflows of capital, GDP per capita, and institutional quality, excluding outliers and countries with population less than a million. 92-country sample excludes countries with missing human capital data. 97-country sample excludes countries with missing restrictions to capital mobility data. The "base" sample is composed of 81 countries for which all the main explanatory variables are available. Average inflows of capital per capita, 1970-2000 include inflows of direct and portfolio equity investment from the IMF, IFS. Inflows are expressed in constant 1996 U.S. dollars. GDP per capita in 1970 is the gross domestic product divided by population in 1970 in PPP basis (in 1996 U.S. dollars). Average institutional quality is the sum of all the rating components from International Country Risk Guide, averaged over the relevant sample period. The components are investment profile, government stability, internal conflict, external conflict, no-corruption index, non-militarized politics, protection from religious tensions, law and order, protection from ethnic tensions, democratic accountability, quality of bureaucracy. The index ranges from 0 to 10 , where a higher score means lower risk. Average years of schooling is years of total schooling in total population, averaged over the relevant sample period. Average distantness is constructed as the weighted average of the distances in thousands of kms from the capital city of the particular country to the capital cities of the other countries, using the total GDP shares of the other countries as weights, averaged over the relevant time period. Average restrictions to capital mobility is the mean value of four dummy variables, averaged over the relevant sample period: 1) Exchange arrangements: separate exchange rates for some or all capital transactions; 2) Payments restrictions on payments for current transactions; 3) Payments restrictions on payments for capital transactions; 4) Surrender or repatriation requirements for export proceeds. See appendix A for detailed explanations of all the variables and sources. 
Table 7: OLS Regressions of Capital Inflows per capita - KLSV Flows Data

Dependent Variable is Average Capital Inflows per capita, 1970-2000

\begin{tabular}{|c|c|c|c|c|c|c|c|c|c|}
\hline & $\begin{array}{l}\text { Whole } \\
\text { World } \\
\text { (1) }\end{array}$ & $\begin{array}{l}\text { Whole } \\
\text { World } \\
(2)\end{array}$ & $\begin{array}{c}\text { Base } \\
\text { Sample } \\
(3)\end{array}$ & $\begin{array}{c}\text { Base } \\
\text { Sample } \\
(4)\end{array}$ & $\begin{array}{c}\text { Base } \\
\text { Sample } \\
(5)\end{array}$ & $\begin{array}{c}\text { Base } \\
\text { Sample } \\
(6)\end{array}$ & $\begin{array}{c}\text { Base } \\
\text { Sample } \\
(7)\end{array}$ & $\begin{array}{c}\text { Base } \\
\text { Sample } \\
(8)\end{array}$ & $\begin{array}{c}\text { Base } \\
\text { Sample } \\
(9)\end{array}$ \\
\hline $\begin{array}{l}\text { Log GDP per } \\
\text { capita (PPP) in } 1970\end{array}$ & $\begin{array}{c}4.89^{* * * *} \\
(0.73)\end{array}$ & $\begin{array}{l}1.19 \\
(0.79)\end{array}$ & $\begin{array}{c}4.87^{* * *} \\
(0.75)\end{array}$ & $\begin{array}{c}0.85 \\
(0.83)\end{array}$ & $\begin{array}{c}3.09^{* * *} \\
(0.84)\end{array}$ & $\begin{array}{c}4.53^{* * *} \\
(0.95)\end{array}$ & $\begin{array}{c}3.65^{* * *} \\
(0.72)\end{array}$ & $\begin{array}{c}0.36 \\
(0.83)\end{array}$ & \\
\hline $\begin{array}{l}\text { Log GDP per } \\
\text { capita }(1990 \$) \text { in } 1970\end{array}$ & & & & & & & & & $\begin{array}{c}0.55 \\
(0.34)\end{array}$ \\
\hline $\begin{array}{l}\text { Average Institutional } \\
\text { Quality, 1984-1997 }\end{array}$ & & $\begin{array}{c}2.39 * * * \\
(0.41)\end{array}$ & & $\begin{array}{c}2.54^{* * *} \\
(0.43)\end{array}$ & & & & $\begin{array}{c}2.16^{* * *} \\
(0.52)\end{array}$ & $\begin{array}{c}2.02^{* * *} \\
(0.45)\end{array}$ \\
\hline $\begin{array}{l}\text { Log Average Years of } \\
\text { Schooling, 1970-1997 }\end{array}$ & & & & & $\begin{array}{c}3.84^{* * *} \\
(1.34)\end{array}$ & & & $\begin{array}{c}0.85 \\
(1.23)\end{array}$ & $\begin{array}{c}0.74 \\
(1.13)\end{array}$ \\
\hline $\begin{array}{l}\text { Log Average } \\
\text { Distantness, 1970-1997 }\end{array}$ & & & & & & $\begin{array}{l}-3.54 \\
(3.90)\end{array}$ & & $\begin{array}{l}-1.60 \\
(3.33)\end{array}$ & $\begin{array}{l}-0.48 \\
(2.92)\end{array}$ \\
\hline $\begin{array}{l}\text { Average Restrictions to } \\
\text { Capital Mobility, } 1970-1997\end{array}$ & & & & & & & $\begin{array}{c}-6.17^{* * *} \\
(2.17)\end{array}$ & $\begin{array}{l}-2.73 \\
(2.04)\end{array}$ & $\begin{array}{l}-2.49 \\
(2.09)\end{array}$ \\
\hline $\begin{array}{l}R^{2} \\
\text { Countries }\end{array}$ & $\begin{array}{c}0.49 \\
61\end{array}$ & $\begin{array}{c}0.64 \\
61\end{array}$ & $\begin{array}{c}0.48 \\
58\end{array}$ & $\begin{array}{c}0.64 \\
58\end{array}$ & $\begin{array}{c}0.51 \\
58\end{array}$ & $\begin{array}{c}0.49 \\
58\end{array}$ & $\begin{array}{c}0.52 \\
58\end{array}$ & $\begin{array}{c}0.65 \\
58\end{array}$ & $\begin{array}{c}0.66 \\
58\end{array}$ \\
\hline
\end{tabular}

Notes: All regressions include a constant and are estimated by OLS with White's correction of heteroscedasticity. Standard errors are in parentheses denoting *** $1 \%, * * 5 \%, * 10 \%$ significance. Samples: 61-country "whole world" sample includes all countries with data available for inflows of capital, GDP per capita, and institutional quality, excluding outliers. The "base" sample is composed of 58 countries for which all the main explanatory variables are available. Average inflows of capital per capita, 1970-1997 are the flows of foreign claims on domestic capital in constant 1990 U.S. dollars, from KLSV data set. GDP per capita in 1970 is the gross domestic product divided by population in 1970 in PPP basis (in 1990 U.S. dollars). Average institutional quality is the sum of all the rating components from International Country Risk Guide, averaged over the relevant sample period. The components are investment profile, government stability, internal conflict, external conflict, no-corruption index, non-militarized politics, protection from religious tensions, law and order, protection from ethnic tensions, democratic accountability, quality of bureaucracy. The index ranges from 0 to 10 , where a higher score means lower risk. Average years of schooling is years of total schooling in total population, averaged over the relevant sample period. Average distantness is constructed as the weighted average of the distances in thousands of kms from the capital city of the particular country to the capital cities of the other countries, using the total GDP shares of the other countries as weights, averaged over the relevant time period. Average restrictions to capital mobility is the mean value of four dummy variables, averaged over the relevant sample period: 1) Exchange arrangements: separate exchange rates for some or all capital transactions; 2) Payments restrictions on payments for current transactions; 3) Payments restrictions on payments for capital transactions; 4) Surrender or repatriation requirements for export proceeds. See appendix A for detailed explanations of all the variables and sources. 
Table 8: OLS Regressions of Capital Inflows per capita - LM Flows Data

Dependent Variable is Average Capital Inflows per capita, 1970-2000

\begin{tabular}{|c|c|c|c|c|c|c|c|c|c|}
\hline & $\begin{array}{c}\text { Whole } \\
\text { World } \\
(1)\end{array}$ & $\begin{array}{c}\text { Whole } \\
\text { World } \\
(2)\end{array}$ & $\begin{array}{c}\text { Base } \\
\text { Sample } \\
(3)\end{array}$ & $\begin{array}{c}\text { Base } \\
\text { Sample } \\
(4)\end{array}$ & $\begin{array}{c}\text { Base } \\
\text { Sample } \\
(5)\end{array}$ & $\begin{array}{c}\text { Base } \\
\text { Sample } \\
(6)\end{array}$ & $\begin{array}{c}\text { Base } \\
\text { Sample } \\
(7)\end{array}$ & $\begin{array}{c}\text { Base } \\
\text { Sample } \\
(8)\end{array}$ & $\begin{array}{c}\text { Base } \\
\text { Sample } \\
(9)\end{array}$ \\
\hline $\begin{array}{l}\text { Log GDP per } \\
\text { capita (PPP) in } 1970\end{array}$ & $\begin{array}{c}1.80^{* * *} \\
(0.38)\end{array}$ & $\begin{array}{c}0.32 \\
(0.25)\end{array}$ & $\begin{array}{c}1.92^{* * *} \\
(0.40)\end{array}$ & $\begin{array}{c}0.32 \\
(0.29)\end{array}$ & $\begin{array}{c}1.14^{* * *} \\
(0.42)\end{array}$ & $\begin{array}{c}1.70^{* * *} \\
(0.36)\end{array}$ & $\begin{array}{c}1.29^{* * *} \\
(0.40)\end{array}$ & $\begin{array}{l}-0.01 \\
(0.32)\end{array}$ & \\
\hline $\begin{array}{l}\text { Log GDP per } \\
\text { capita }(1996 \$) \text { in } 1970\end{array}$ & & & & & & & & & $\begin{array}{l}-0.18 \\
(0.22)\end{array}$ \\
\hline $\begin{array}{l}\text { Average Institutional } \\
\text { Quality, 1984-1998 }\end{array}$ & & $\begin{array}{c}1.36^{* * *} \\
(0.30)\end{array}$ & & $\begin{array}{c}1.36^{* * *} \\
(0.31)\end{array}$ & & & & $\begin{array}{c}1.18^{* * *} \\
(0.34)\end{array}$ & $\begin{array}{c}1.24^{* * *} \\
(0.36)\end{array}$ \\
\hline $\begin{array}{l}\text { Log Average Years of } \\
\text { Schooling, 1970-1998 }\end{array}$ & & & & & $\begin{array}{c}2.26^{* * *} \\
(0.81)\end{array}$ & & & $\begin{array}{c}0.21 \\
(1.07)\end{array}$ & $\begin{array}{c}0.35 \\
(1.12)\end{array}$ \\
\hline $\begin{array}{l}\text { Log Average } \\
\text { Distantness, 1970-1998 }\end{array}$ & & & & & & $\begin{array}{l}-2.45^{*} \\
(1.41)\end{array}$ & & $\begin{array}{l}-1.44 \\
(1.26)\end{array}$ & $\begin{array}{l}-1.36 \\
(1.29)\end{array}$ \\
\hline $\begin{array}{l}\text { Average Restrictions to } \\
\text { Capital Mobility, } 1970-1998\end{array}$ & & & & & & & $\begin{array}{l}-3.25^{* *} \\
(1.52)\end{array}$ & $\begin{array}{l}-1.77 \\
(1.29)\end{array}$ & $\begin{array}{l}-1.93 \\
(1.28)\end{array}$ \\
\hline $\begin{array}{l}R^{2} \\
\text { Countries }\end{array}$ & $\begin{array}{c}0.27 \\
60\end{array}$ & $\begin{array}{c}0.51 \\
60\end{array}$ & $\begin{array}{c}0.29 \\
56\end{array}$ & $\begin{array}{c}0.51 \\
56\end{array}$ & $\begin{array}{c}0.34 \\
56\end{array}$ & $\begin{array}{c}0.33 \\
56\end{array}$ & $\begin{array}{l}0.35 \\
56\end{array}$ & $\begin{array}{c}0.53 \\
56\end{array}$ & $\begin{array}{c}0.53 \\
56\end{array}$ \\
\hline
\end{tabular}

Notes: All regressions include a constant and are estimated by OLS with White's correction of heteroscedasticity. Standard errors are in parentheses denoting *** $1 \%, * * 5 \%, * 10 \%$ significance. Samples: 60-country "whole world" sample includes all countries with data available for inflows of capital, GDP per capita, and institutional quality, excluding outliers. The "base" sample is composed of 56 countries for which all the main explanatory variables are available. Average inflows of capital per capita, 1970-1998 are the flows of foreign claims on domestic capital in constant 1996 U.S. dollars, from LM data set. GDP per capita in 1970 is the gross domestic product divided by population in 1970 in PPP basis (in 1996 U.S. dollars). Average institutional quality is the sum of all the rating components from International Country Risk Guide, averaged over the relevant sample period. The components are investment profile, government stability, internal conflict, external conflict, no-corruption index, non-militarized politics, protection from religious tensions, law and order, protection from ethnic tensions, democratic accountability, quality of bureaucracy. The index ranges from 0 to 10, where a higher score means lower risk. Average years of schooling is years of total schooling in total population, averaged over the relevant sample period. Average distantness is constructed as the weighted average of the distances in thousands of kms from the capital city of the particular country to the capital cities of the other countries, using the total GDP shares of the other countries as weights, averaged over the relevant time period. Average restrictions to capital mobility is the mean value of four dummy variables, averaged over the relevant sample period: 1) Exchange arrangements: separate exchange rates for some or all capital transactions; 2) Payments restrictions on payments for current transactions; 3) Payments restrictions on payments for capital transactions; 4) Surrender or repatriation requirements for export proceeds. See appendix A for detailed explanations of all the variables and sources. 
Table 9: OLS Regressions of Capital Inflows per capita - KLSV Flows Data

Dependent Variable is Average Capital Inflows per capita, 1985-1997

\begin{tabular}{lcc}
\hline \hline & $(1)$ & $(2)$ \\
\hline Institutional & $4.53^{* * *}$ & $3.60^{* * *}$ \\
Quality in 1984 & $(0.57)$ & $(1.02)$ \\
Log GDP per & & 2.65 \\
capita (PPP) in 1984 & & $(2.64)$ \\
$R^{2}$ & 0.59 & 0.59 \\
Countries & 54 & 54 \\
\hline
\end{tabular}

Notes: All regressions include a constant and are estimated by White's correction of heteroscedasticity. Standard errors are in parentheses denoting *** $1 \%, * * 5 \%, * 10 \%$ significance. The regressions are estimated using 54 country out of 58 country "base" sample due to missing data for BGD, IRN, NIC, and SEN in the year of 1984. Average inflows of capital per capita, 1985-1997 are the flows of foreign claims on domestic capital in constant 1990 U.S. dollars, from KLSV data set. GDP per capita in 1970 is the gross domestic product divided by population in 1970 in PPP basis (in 1990 U.S. dollars). Average institutional quality is the sum of all the rating components from International Country Risk Guide, averaged over the relevant sample period. The components are investment profile, government stability, internal conflict, external conflict, no-corruption index, non-militarized politics, protection from religious tensions, law and order, protection from ethnic tensions, democratic accountability, quality of bureaucracy. The index ranges from 0 to 10, where a higher score means lower risk. See appendix A for detailed explanations of all the variables and sources. 
Table 10: IV Regressions of Capital Inflows per capita - KLSV Flows Data

$(2)$

\section{Panel A: Two-Stage Least Squares}

$\begin{array}{lcc}\text { Average Institutional } & 3.76^{* * *} & 10.86^{* *} \\ \text { Quality, 1984-1997 } & (0.85) & (5.34) \\ \text { Log GDP per } & & -12.65 \\ \text { capita (PPP) in 1970 } & & (8.18)\end{array}$

Panel B: First Stage for Average Institutional Quality in 1984-1997

\begin{tabular}{lcc} 
Log European & $-1.02^{* * *}$ & $-0.30^{*}$ \\
Settler Mortality & $(0.19)$ & $(0.18)$ \\
Log GDP per & & $1.26^{* * *}$ \\
capita (PPP) in 1970 & & $(0.19)$ \\
$R^{2}$ & 0.39 & 0.69 \\
\hline
\end{tabular}

Panel C: Ordinary Least Squares

$\begin{array}{lcc}\text { Average Institutional } & 2.23^{* * *} & 2.33^{* * *} \\ \text { Quality, 1984-1997 } & (0.64) & (0.76) \\ \text { Log GDP per } & & -0.22 \\ \text { capita (PPP) in 1970 } & & (1.01) \\ \text { Countries } & 34 & 34\end{array}$

Notes: Panel A reports the two-stage least-squares estimates, instrumenting for institutional quality using log settler mortality; Panel B reports the corresponding first stage. Panel C reports the coefficient from an OLS regression of the dependent variable against average institutional quality and other controls. All regressions include a constant and are estimated by White's correction of heteroscedasticity. Standard errors are in parentheses denoting *** $1 \%, * * 5 \%, *$ $10 \%$ significance. The regressions are estimated using 34 country (former colonies) out of 58 country "base" sample due to the availability of log settler mortality data. Average inflows of capital per capita, 1970-1997 are the flows of foreign claims on domestic capital in 1990 constant U.S. dollars, from KLSV data set. GDP per capita in 1970 is the gross domestic product divided by population in PPP basis (in 1990 U.S. dollars). Average institutional quality is the sum of all the rating components from International Country Risk Guide, averaged over the relevant sample period. The components are investment profile, government stability, internal conflict, external conflict, no-corruption index, non-militarized politics, protection from religious tensions, law and order, protection from ethnic tensions, democratic accountability, quality of bureaucracy. The index ranges from 0 to 10, where a higher score means lower risk. Log European settlers mortality data are from Acemoglu, Johnson, and Robinson (2001). See table 1 and appendix A for more detailed variable descriptions and sources. 
Table 11: Tests for Validity and Excludability of Instruments - KLSV Flows Data

Panel A: Second Stage with Log Settler Mortality as Exogenous Variable

$\begin{array}{lc}\text { Average Institutional } & 1.95^{* *} \\ \text { Quality, 1984-1997 } & (0.90) \\ \text { Log European } & -1.84 \\ \text { Settler Mortality } & (1.16)\end{array}$

Panel B: First Stage for Average Institutional Quality in 1984-1997

\begin{tabular}{lc} 
British Legal Origin & $-1.44^{* * *}$ \\
& $(0.36)$ \\
English Language & $2.79^{* * *}$ \\
& $(0.41)$ \\
Log European & $-0.98^{* * *}$ \\
Settler Mortality & $(0.14)$ \\
$R^{2}$ & 0.66 \\
\hline
\end{tabular}

Panel C: Results from Overidentification Test

$\mathrm{p}$-value (J test) $\quad 0.55$

Countries 34

Notes: Panel A reports the two-stage least-squares estimates, instrumenting for institutional quality using "other" instruments and where log settler mortality is entered into the regression as an exogenous variable; Panel B reports the corresponding first stage. Panel $\mathrm{C}$ reports the p-value for Hansen $J$ test, where the null hypothesis is that instruments for are valid. All regressions include a constant and are estimated by White's correction of heteroscedasticity. Standard errors are in parentheses denoting $* * * 1 \%, * * 5 \%, * 10 \%$ significance. The regressions are estimated using 34 country (former colonies) out of 58 country "base" sample due to the availability of log settler mortality data. Average inflows of capital per capita, 1970-1997 are the flows of foreign claims on domestic capital in 1990 constant U.S. dollars, from KLSV data set. GDP per capita in 1970 is the gross domestic product divided by population in PPP basis (in 1990 U.S. dollars). Average institutional quality is the sum of all the rating components from International Country Risk Guide, averaged over the relevant sample period. The components are investment profile, government stability, internal conflict, external conflict, no-corruption index, non-militarized politics, protection from religious tensions, law and order, protection from ethnic tensions, democratic accountability, quality of bureaucracy. The index ranges from 0 to 10, where a higher score means lower risk. Log European settlers mortality from Acemoglu, Johnson, and Robinson (2001). See table 1 and appendix A for more detailed variable descriptions and sources. 
Table C-1: Monte Carlo Exercise

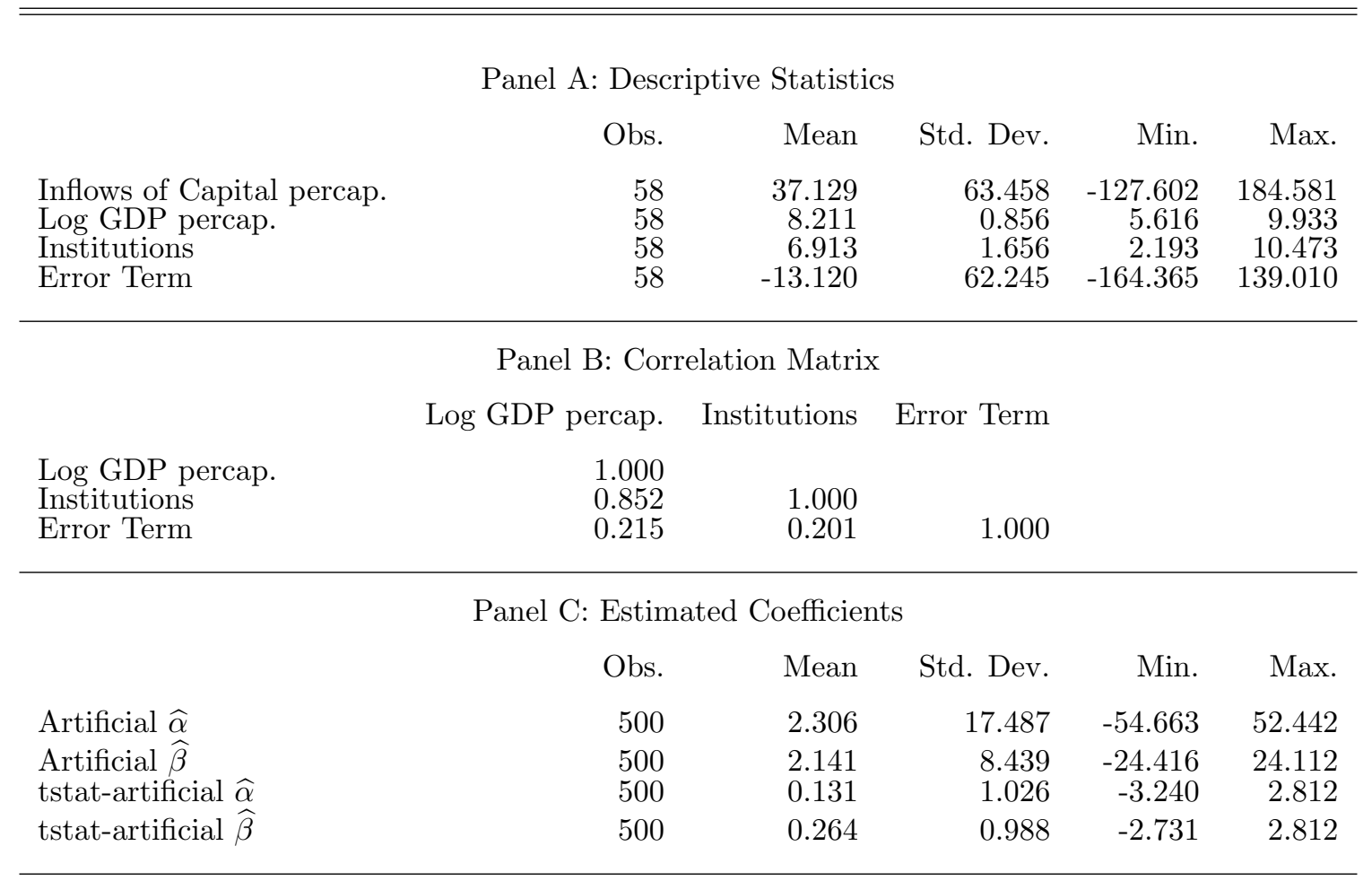

Notes: We generate a random sample for each variable, where the size is equal to our actual KLSV 58 "base" sample and the means, standard deviations and correlations correspond to those of the actual data of 58 countries. We then generate an artificial dependent variable, $\tilde{F}$, average inflows of capital per capita, by calculating, $\tilde{F}_{i}=$ $20+2.0 \log \tilde{Y}_{i}+2.0 \tilde{I}_{i}+\tilde{\varepsilon}_{i}$ where $\tilde{Y}_{i}$ is the randomly generated $\log$ of GDP per capita, $\tilde{I}_{i}$ is the randomly generated institutional quality and $\tilde{\varepsilon_{i}}$ is a random error term. Descriptive statistics and correlation matrix in panels A and B correspond to those of the artificial data. Summary statistics for artificial $\widehat{\alpha}$ and artificial $\widehat{\beta}$ in panel $\mathrm{C}$ correspond to those of the estimated coefficients of regressing 500 times $\tilde{F}_{i}$ on $\tilde{Y}_{i}$ and $\tilde{I}_{i}$ using OLS. 
Table C-2: Perturbation Exercise

Sample: 58-country base sample for the KLSV capital flows data, 1970-1997

\begin{tabular}{lcc} 
& & \\
& Log GDP percap. & Institutions \\
Unperturbed Solution & 0.811 & 2.547 \\
Mean & 0.808 & 2.548 \\
Median & 0.809 & 2.547 \\
Std. Dev. & 0.069 & 0.032 \\
Lowest Value & 0.587 & 2.461 \\
Highest Value & 1.000 & 2.645 \\
Percent Agreement & 100.0 & 100.0 \\
t-value, mean=unperturbed & -1.207 & 0.744 \\
$P_{\text {lim }}$ & 0.811 & 2.547 \\
t-value, mean=Plim & -1.213 & 0.761 \\
\hline
\end{tabular}

Notes: We first generate artificial data by adding a rounded error term to the variables log GDP per capita and institutions of the 58-country sample. We then regress 1000 times the actual dependent variable, average inflows of capital per capita, 1970-1997, on the "perturbed" data using OLS, $F_{i}=\mu^{\prime \prime}+\alpha^{\prime \prime} \log \left(Y_{i}+E\right)+\beta^{\prime \prime}\left(I_{i}+E\right)+\varepsilon_{i}^{p}$, where $E$ denotes the added rounded error term. The unperturbed solution that is reported in the table corresponds to the actual data. The rest of the summary statistics correspond to the "perturbed" coefficients $\alpha^{\prime \prime}$ and $\beta^{\prime \prime}$. The "percentage agreement" is the percentage of the "perturbed" coefficients that agree with the unperturbed solution to at least one digit. $P_{l i m}$ is the center of the distribution of the "perturbed" coefficients assuming a large sample size. 
Table D-1: Robustness Checks for OLS Regressions of Capital Inflows per capita I- KLSV Data

Dependent Variable is Average Capital Inflows per capita

\begin{tabular}{|c|c|c|c|c|c|c|c|c|}
\hline Time Period & $\begin{array}{l}1970-97 \\
(1)\end{array}$ & $\begin{array}{l}1990-97 \\
(2)\end{array}$ & $\begin{array}{l}1970-97 \\
(3)\end{array}$ & $\begin{array}{l}1990-97 \\
(4)\end{array}$ & $\begin{array}{c}1990-97 \\
(5)\end{array}$ & $\begin{array}{l}1970-97 \\
(6)\end{array}$ & $\begin{array}{l}1970-97 \\
(7)\end{array}$ & $\begin{array}{c}1970-97 \\
(8)\end{array}$ \\
\hline $\begin{array}{l}\text { Log GDP per } \\
\text { capita (PPP) in } 1970\end{array}$ & $\begin{array}{c}0.83 \\
(0.85)\end{array}$ & $\begin{array}{c}3.19 \\
(3.80)\end{array}$ & $\begin{array}{c}0.91 \\
(0.83)\end{array}$ & $\begin{array}{l}-3.13 \\
(4.76)\end{array}$ & $\begin{array}{l}-0.94 \\
(4.65)\end{array}$ & $\begin{array}{c}0.63 \\
(0.89)\end{array}$ & $\begin{array}{c}0.83 \\
(0.86)\end{array}$ & $\begin{array}{c}0.94 \\
(1.02)\end{array}$ \\
\hline $\begin{array}{l}\text { Average Institutional } \\
\text { Quality, 1984-1997 }\end{array}$ & $\begin{array}{c}2.56^{* * *} \\
(0.45)\end{array}$ & $\begin{array}{c}6.31^{* * *} \\
(2.07)\end{array}$ & $\begin{array}{c}2.49^{* * *} \\
(0.43)\end{array}$ & $\begin{array}{c}10.00^{* * *} \\
(3.28)\end{array}$ & $\begin{array}{l}8.00^{* *} \\
(3.17)\end{array}$ & $\begin{array}{c}2.46^{* * *} \\
(0.51)\end{array}$ & $\begin{array}{c}2.58^{* * *} \\
(0.58)\end{array}$ & $\begin{array}{c}2.34^{* * *} \\
(0.55)\end{array}$ \\
\hline $\begin{array}{l}\text { Log Average Inflation } \\
\text { Volatility, 1970-1997 }\end{array}$ & $\begin{array}{c}0.15 \\
(0.73)\end{array}$ & & & & & & & \\
\hline $\begin{array}{l}\text { Average Corporate Tax } \\
\text { Rate, 1970-1997 }\end{array}$ & & $\begin{array}{c}-0.68^{* *} \\
(0.27)\end{array}$ & & & & & & \\
\hline $\begin{array}{l}\text { Log Average Trade } \\
\text { Openness, 1970-1997 }\end{array}$ & & & $\begin{array}{l}0.83 \\
(0.87)\end{array}$ & & & & & \\
\hline FDI Restrictions in 1990 & & & & $\begin{array}{l}-1.38 \\
(2.30)\end{array}$ & & & & \\
\hline FDI Incentives in 1990 & & & & & $\begin{array}{c}-4.77^{*} \\
(2.67)\end{array}$ & & & \\
\hline $\begin{array}{l}\text { Average Paved Roads, } \\
\text { 1970-1997 }\end{array}$ & & & & & & $\begin{array}{c}0.02 \\
(0.02)\end{array}$ & & \\
\hline $\begin{array}{l}\text { Log Average Bank Assets, } \\
1970-1997\end{array}$ & & & & & & & $\begin{array}{l}-0.16 \\
(1.02)\end{array}$ & \\
\hline $\begin{array}{l}\text { Log Average Stock Market } \\
\text { Value Traded, 1970-1997 }\end{array}$ & & & & & & & & $\begin{array}{c}0.27 \\
(0.27)\end{array}$ \\
\hline$R^{2}$ & 0.64 & 0.59 & $\begin{array}{c}0.65 \\
58\end{array}$ & $\begin{array}{l}0.47 \\
33^{b}\end{array}$ & $\begin{array}{c}0.49 \\
33^{b}\end{array}$ & $\begin{array}{l}0.65 \\
57^{c}\end{array}$ & $\begin{array}{c}0.66 \\
58\end{array}$ & $\begin{array}{l}0.62 \\
50^{d}\end{array}$ \\
\hline Countries & 58 & $42^{a}$ & 58 & $33^{b}$ & $33^{b}$ & $57^{c}$ & 58 & $50^{d}$ \\
\hline
\end{tabular}

Notes: All regressions include a constant and are estimated by OLS with White's correction of heteroscedasticity. Standard errors are in parentheses denoting *** $1 \%, * * 5 \%, * 10 \%$. See appendix A for more detailed variable descriptions and sources. 
Table D-2: Robustness Checks for OLS Regressions of Capital Inflows per capita II- KLSV Data Dependent Variable is Average Capital Inflows per capita

\begin{tabular}{|c|c|c|c|c|c|}
\hline Time Period & $\begin{array}{c}1970-97 \\
(1)\end{array}$ & $\begin{array}{c}1970-97 \\
(2)\end{array}$ & $\begin{array}{c}1970-97 \\
(3)\end{array}$ & $\begin{array}{l}1970-97 \\
(4)\end{array}$ & $\begin{array}{c}1994-97 \\
(5)\end{array}$ \\
\hline $\begin{array}{l}\text { Log GDP per } \\
\text { capita (PPP) in } 1970\end{array}$ & $\begin{array}{c}0.84 \\
(1.61)\end{array}$ & & $\begin{array}{c}0.91 \\
(0.84)\end{array}$ & $\begin{array}{c}0.68 \\
(0.86)\end{array}$ & $\begin{array}{c}8.43^{* * *} \\
(3.16)\end{array}$ \\
\hline $\begin{array}{l}\text { Average Institutional } \\
\text { Quality, 1984-1997 }\end{array}$ & $\begin{array}{c}2.54^{* * *} \\
(0.50)\end{array}$ & $\begin{array}{c}2.44^{* * *} \\
(0.46)\end{array}$ & $\begin{array}{c}2.49^{* * *} \\
(0.43)\end{array}$ & $\begin{array}{c}2.55^{* * *} \\
(0.43)\end{array}$ & $\begin{array}{c}8.19^{* * *} \\
(3.18)\end{array}$ \\
\hline $\begin{array}{l}\text { Log Average TFP, } \\
1970-1997\end{array}$ & $\begin{array}{c}0.02 \\
(3.48)\end{array}$ & & & & \\
\hline $\begin{array}{l}\text { Log Capital Stock } \\
\text { per capita in } 1970\end{array}$ & & $\begin{array}{c}0.73 \\
(0.64)\end{array}$ & & & \\
\hline Oil Dummy & & & $\begin{array}{l}-1.13 \\
(1.41)\end{array}$ & & \\
\hline Sub-Sahara Dummy & & & & $\begin{array}{l}-2.12 \\
(1.40)\end{array}$ & \\
\hline Malaria in 1994 & & & & & $\begin{array}{c}6.54 \\
(5.53)\end{array}$ \\
\hline $\begin{array}{l}R^{2} \\
\text { Countries }\end{array}$ & $\begin{array}{c}0.64 \\
58\end{array}$ & $\begin{array}{c}0.64 \\
58\end{array}$ & $\begin{array}{l}0.64 \\
58\end{array}$ & $\begin{array}{c}0.65 \\
58\end{array}$ & $\begin{array}{l}0.46 \\
48^{a}\end{array}$ \\
\hline
\end{tabular}

Notes: All regressions include a constant and are estimated by OLS with White's correction of heteroscedasticity. Standard errors are in parentheses denoting *** $1 \%,{ }^{*} 5 \%,{ }^{*} 10 \% .{ }^{a} 48$-country sample due to missing data on the dependent variable for the year 1994. See appendix A for more detailed variable descriptions and sources. 
Table D-3: Robustness Checks for OLS Regressions of Capital Inflows per capita III- KLSV Data Dependent Variable is Average Capital Inflows per capita

\begin{tabular}{lcccc}
\hline \hline Time Period & $\begin{array}{c}1990-97 \\
(1)\end{array}$ & $\begin{array}{c}1990-97 \\
(2)\end{array}$ & $\begin{array}{c}1970-97 \\
(3)\end{array}$ & $\begin{array}{c}1990-97 \\
(4)\end{array}$ \\
\hline Log GDP per & -1.17 & -2.66 & 0.78 & 0.89 \\
capita (PPP) in 1970 & $(3.67)$ & $(4.65)$ & $(0.81)$ & $(3.13)$ \\
& & & \\
Average Institutional & $8.26^{* *}$ & $8.18^{* *}$ & $2.44^{* * *}$ & $6.97^{* * *}$ \\
Quality, 1984-1997 & $(3.50)$ & $(3.46)$ & $(0.42)$ & $(2.22)$ \\
Average Sovereign Risk & -0.11 & & & \\
Moody's, 1970-1997 & $(0.52)$ & & & \\
Average Sovereign Risk & & -0.42 & & \\
S\&P, 1970-1997 & & $(0.42)$ & & \\
Log Average Reuters, & & & 0.29 & \\
1970-1997 & & & & \\
Average Foreign Banks & & & & \\
Asset Share, 1990-1997 & & & & \\
$R^{2}$ & 0.45 & 0.46 & 0.65 & 0.49 \\
Countries & $36^{a}$ & $35^{b}$ & 58 & $49^{c}$ \\
\hline
\end{tabular}

Notes: All regressions include a constant and are estimated by OLS with White's correction of heteroscedasticity. Standard errors are in parentheses denoting *** $1 \%, * * 5 \%, * 10 \% .{ }^{a}$ Limited 36 -country sample due to missing data on Moody's sovereign ratings. ${ }^{b}$ Limited 35-country sample due to missing data on S\&P's sovereign ratings. ${ }^{c}$ Limited 44-country sample due to missing data on foreign banks assets. See appendix A for more detailed variable descriptions and sources. 
Table D-4: Robustness Checks for OLS Regressions of Capital Inflows per capita - LM Flows Data Dependent Variable is Average Capital Inflows per capita, 1970-2000

\begin{tabular}{lcccc}
\hline \hline Dep.Var.: & $\begin{array}{c}\text { FDI and } \\
\text { Portfolio } \\
(1)\end{array}$ & $\begin{array}{c}\text { FDI and } \\
\text { Portfolio } \\
(2)\end{array}$ & $\begin{array}{c}\text { FDI, Portfolio } \\
\text { and Debt } \\
(3)\end{array}$ & $\begin{array}{c}\text { FDI, Portfolio } \\
\text { and Debt } \\
(4)\end{array}$ \\
\hline $\begin{array}{l}\text { Log GDP per } \\
\text { capita (PPP) in 1970 }\end{array}$ & $\begin{array}{c}(0.32 \\
\text { Average Institutional }\end{array}$ & $\begin{array}{c}-0.01 \\
(0.32)\end{array}$ & $\begin{array}{c}0.93 \\
(0.59)\end{array}$ & 0.02 \\
Quality, 1984-1998 & $\left(0.36^{* * *}\right.$ & $\begin{array}{c}1.18^{* * *} \\
(0.34)\end{array}$ & $3.22^{* * *}$ & $(0.56)$ \\
Log Average Years of & & 0.21 & & $2.41^{* * *}$ \\
Schooling, 1970-1998 & & $(1.07)$ & & $(0.61)$ \\
Log Average & & -1.44 & & 1.31 \\
Distantness, 1970-1998 & & $(1.26)$ & & -8.19 \\
Average Restrictions to & & -1.77 & & $(2.24)$ \\
Capital Mobility, 1970-1998 & & $(1.29)$ & & -3.61 \\
$R^{2}$ & & 0.53 & 0.70 & $(2.03)$ \\
Countries & 0.51 & 56 & 56 & 0.70 \\
\hline
\end{tabular}

Notes: All regressions include a constant and are estimated by OLS with White's correction of heteroscedasticity. Standard errors are in parentheses denoting *** $1 \%, * * 5 \%, * 10 \%$ significance. See table 1 and appendix A for more detailed variable descriptions and sources. 
Table D-5: Robustness Checks for OLS Regressions of Capital Inflows per capita by Decades- KLSV Data

Dependent Variable is Average Capital Inflows per capita (over the relevant time period)

\begin{tabular}{|c|c|c|c|c|c|c|c|}
\hline Time Period & $\begin{array}{l}1970-97 \\
(1)\end{array}$ & $\begin{array}{l}1970-95 \\
(2)\end{array}$ & $\begin{array}{l}1970-79 \\
(3)\end{array}$ & $\begin{array}{c}1980-89 \\
(4)\end{array}$ & $\begin{array}{l}1990-97 \\
(5)\end{array}$ & $\begin{array}{l}1985-97 \\
(6)\end{array}$ & $\begin{array}{l}1985-95 \\
\quad(7)\end{array}$ \\
\hline $\begin{array}{l}\text { Log GDP per capita } \\
(\mathrm{PPP}) \text { (initial year) }\end{array}$ & $\begin{array}{c}0.36 \\
(0.83)\end{array}$ & $\begin{array}{c}0.43 \\
(0.90)\end{array}$ & $\begin{array}{c}0.54 \\
(1.30)\end{array}$ & $\begin{array}{c}0.06 \\
(1.82)\end{array}$ & $\begin{array}{l}-1.56 \\
(3.21)\end{array}$ & $\begin{array}{l}-1.76 \\
(3.09)\end{array}$ & $\begin{array}{l}-1.98 \\
(3.05)\end{array}$ \\
\hline $\begin{array}{l}\text { Average Institutional } \\
\text { Quality (over the time period) }\end{array}$ & $\begin{array}{c}2.16^{* * *} \\
(0.52)\end{array}$ & $\begin{array}{c}1.93^{* * *} \\
(0.47)\end{array}$ & $\begin{array}{c}0.71^{* *} \\
(0.32)\end{array}$ & $\begin{array}{c}0.80 \\
(0.49)\end{array}$ & $\begin{array}{c}4.78^{* * *} \\
(1.59)\end{array}$ & $\begin{array}{c}4.40^{* * *} \\
(1.38)\end{array}$ & $\begin{array}{c}4.28 * * * \\
(1.25)\end{array}$ \\
\hline $\begin{array}{l}\text { Log Average Years of Schooling } \\
\text { (over the time period) }\end{array}$ & $\begin{array}{c}0.85 \\
(1.23)\end{array}$ & $\begin{array}{c}0.60 \\
(1.21)\end{array}$ & $\begin{array}{l}1.78 \\
(1.60)\end{array}$ & $\begin{array}{c}0.36 \\
(1.40)\end{array}$ & $\begin{array}{c}4.51 \\
(3.61)\end{array}$ & $\begin{array}{l}2.89 \\
(2.53)\end{array}$ & $\begin{array}{l}2.19 \\
(2.47)\end{array}$ \\
\hline $\begin{array}{l}\text { Log Average Distantness } \\
\text { (over the time period) }\end{array}$ & $\begin{array}{l}-1.60 \\
(3.33)\end{array}$ & $\begin{array}{l}-0.38 \\
(3.76)\end{array}$ & $\begin{array}{l}-2.15 \\
(3.87)\end{array}$ & $\begin{array}{c}2.42 \\
(4.83)\end{array}$ & $\begin{array}{c}-11.42^{*} \\
(6.31)\end{array}$ & $\begin{array}{l}-5.88 \\
(5.34)\end{array}$ & $\begin{array}{l}-3.62 \\
(6.59)\end{array}$ \\
\hline $\begin{array}{l}\text { Average Restrictions to Capital } \\
\text { Mobility (over the time period) }\end{array}$ & $\begin{array}{l}-2.73 \\
(2.04)\end{array}$ & $\begin{array}{l}-2.62 \\
(2.03)\end{array}$ & $\begin{array}{l}-0.23 \\
(1.83)\end{array}$ & $\begin{array}{l}-3.67 \\
(2.38)\end{array}$ & $\begin{array}{c}-7.91^{*} \\
(4.04)\end{array}$ & $\begin{array}{c}-9.00^{* * *} \\
(3.03)\end{array}$ & $\begin{array}{c}-10.27^{* * *} \\
(3.41)\end{array}$ \\
\hline $\begin{array}{l}R^{2} \\
\text { Countries }\end{array}$ & $\begin{array}{l}0.65 \\
58\end{array}$ & $\begin{array}{l}0.59 \\
58\end{array}$ & $\begin{array}{l}0.29 \\
54^{a}\end{array}$ & $\begin{array}{l}0.25 \\
57\end{array}$ & $\begin{array}{l}0.54 \\
50\end{array}$ & $\begin{array}{l}0.65 \\
54\end{array}$ & $\begin{array}{c}0.60 \\
54\end{array}$ \\
\hline
\end{tabular}

Notes: All regressions include a constant and are estimated by OLS with White's correction of heteroscedasticity. Standard errors are in parentheses denoting $* * * 1 \%, * * 5 \%, * 10 \%$ significance. Smaller samples are due to missing data for corresponding time period. See table 1 and appendix A for more detailed variable descriptions and sources. 
Figure 1: Total Equity Inflows per Capita to Rich and Poor Countries, 1970-2000

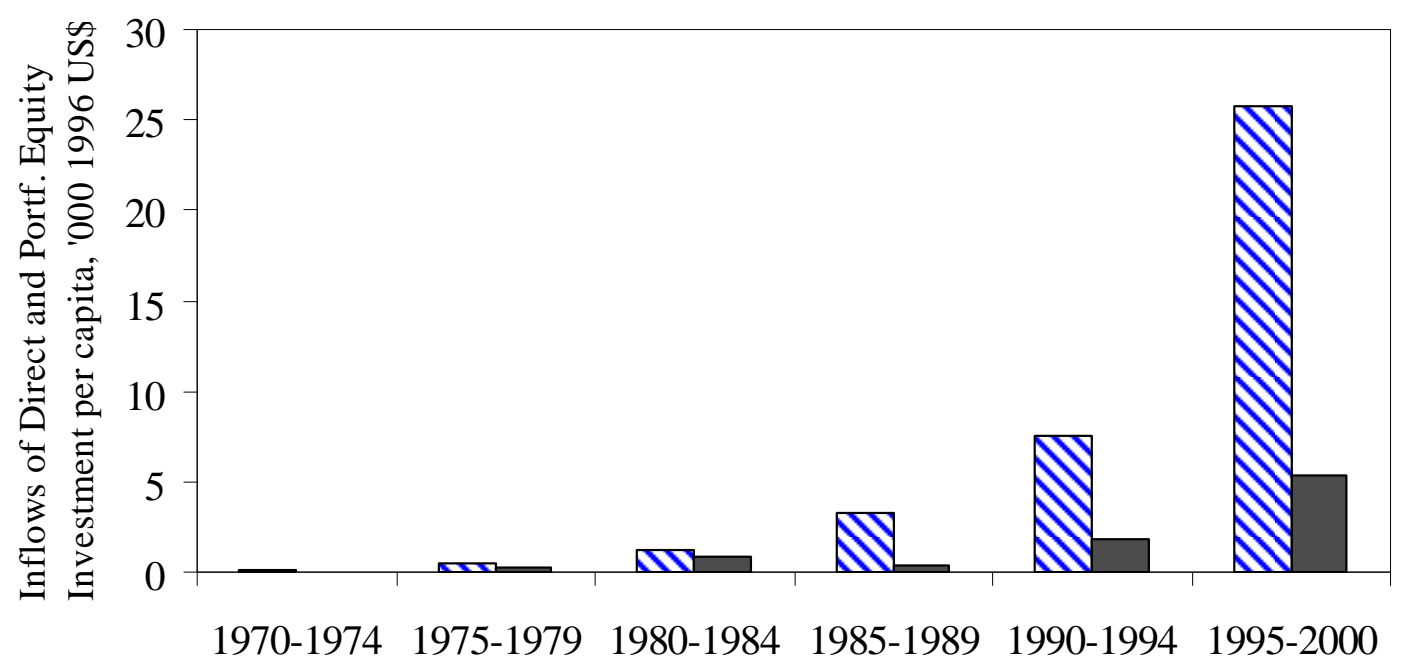

\$ Rich Countries $\square$ Poor Countries

Notes: Inflows of total equity (FDI and portfolio equity investment) divided by population are based on the IMF, IFS data in 1996 US\$. Data are for 98 countries and averaged over 5 year periods. FDI inflows correspond to direct investment in reporting economy (line 78bed) which includes equity capital, reinvested earnings, other capital, and financial derivatives associated with various intercompany transactions between affiliated enterprises. Portfolio equity inflows correspond to equity liabilities (line 78bmd) which includes shares, stock participations, and similar documents that usually denote ownership of equity. Rich countries include 23 high GDP per capita countries that are classified as "rich" by the World Bank; poor countries denote the 75 remaining ones. 
Figure 2: Evolution of Institutional Quality Index, 1984-2000: Sub-components

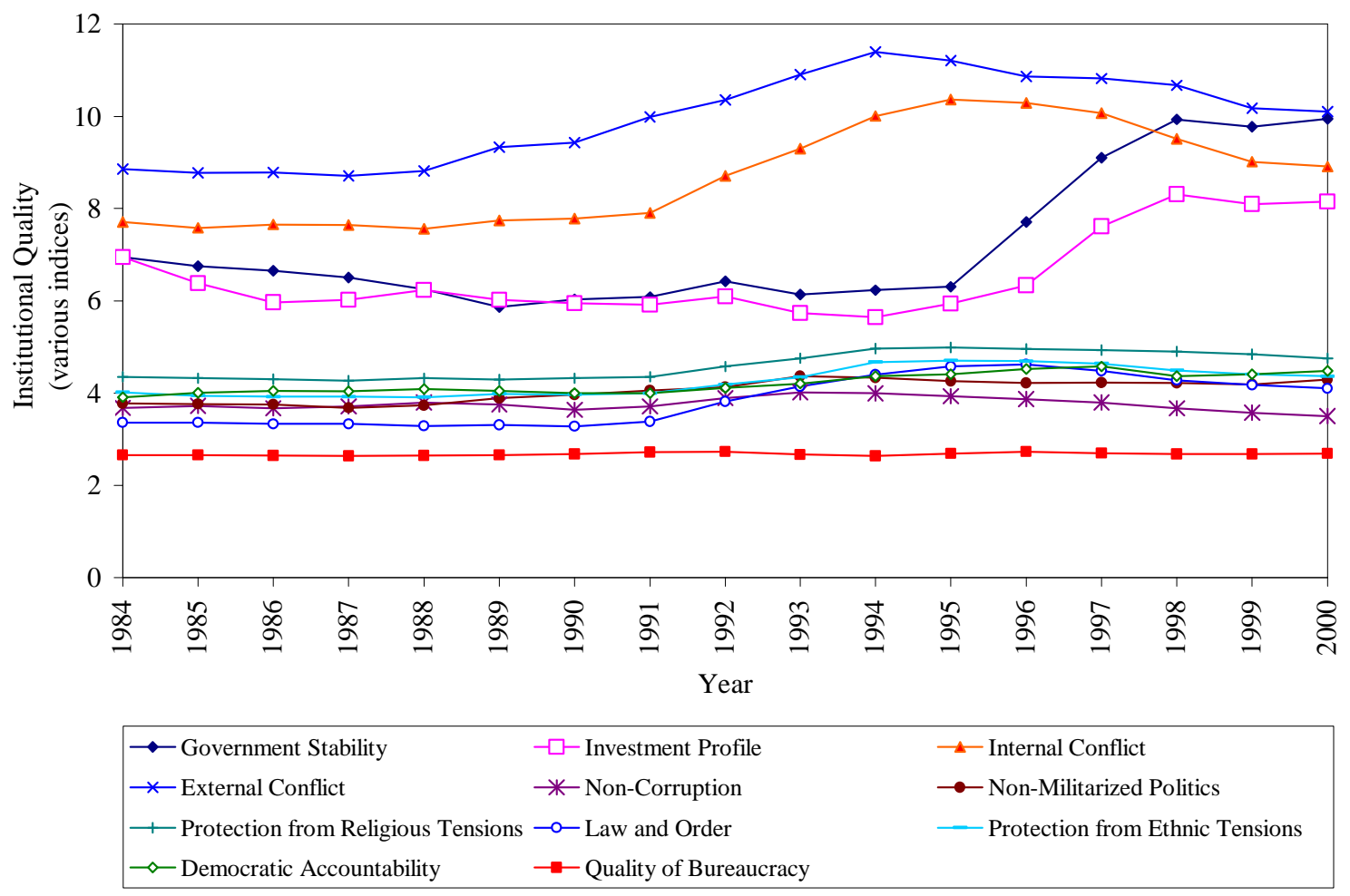

Notes: Government Stability: The government's ability to carry out its declared program(s), and its ability to stay in office. Average yearly rating from 0 to 12, where a higher score means lower risk. Investment Profile: This risk rating is the sum of three subcomponents, each with a maximum score of 4 points and a minimum score of 0 points. A score of 4 points equates to low risk. The subcomponents are: Contract Viability/Expropriation, Profits Repatriation, Payment Delays. Internal Conflict: Political violence in the country and its actual or potential impact on governance. Average yearly rating from 0 to 12, where a higher score means lower risk. External Conflict: Assessment both of the risk to the incumbent government from foreign action, ranging from non-violent external pressure (diplomatic pressures, withholding of aid, trade restrictions, territorial disputes, sanctions, etc.) to violent external pressure (cross-border conflicts to all-out war). Average yearly rating from 0 to 12, where a higher score means lower risk. Non-corruption: Assessment of corruption within the political system. Average yearly rating from 0 to 6 , where a higher score means lower risk. Non-militarized Politics: Protection from the military involvement in politics. Average yearly rating from 0 to 6 , where a higher score means lower risk. Protection from Religious Tensions: Protection from the religious tensions in society. Average yearly rating from 0 to 6 , where a higher score means lower risk. Law and Order: The law sub-component is an assessment of the strength and impartiality of the legal system; the order sub-component is an assessment of popular observance of the law. Average yearly rating from 0 to 6 , where a higher score means lower risk. Protection from Ethnic Tensions: Assessment of the degree of tension within a country attributable to racial, nationality, or language divisions. Average yearly rating from 0 to 12 , where a higher score means lower risk. Democratic Accountability: Average yearly rating from 0 to 6 , where a higher score means lower risk. In general, the highest number of risk points is assigned to alternating democracies, while the lowest number of risk points is assigned to authoritarian regimes. Quality of Bureaucracy: Institutional strength and quality of the bureaucracy is another shock absorber that tends to minimize revisions of policy when governments change. Average yearly rating from 0 to 4 , where a higher score means lower risk. 
Figure 3: Evolution of Institutional Quality Index, 1984-2000: Sub-components for Developing Countries

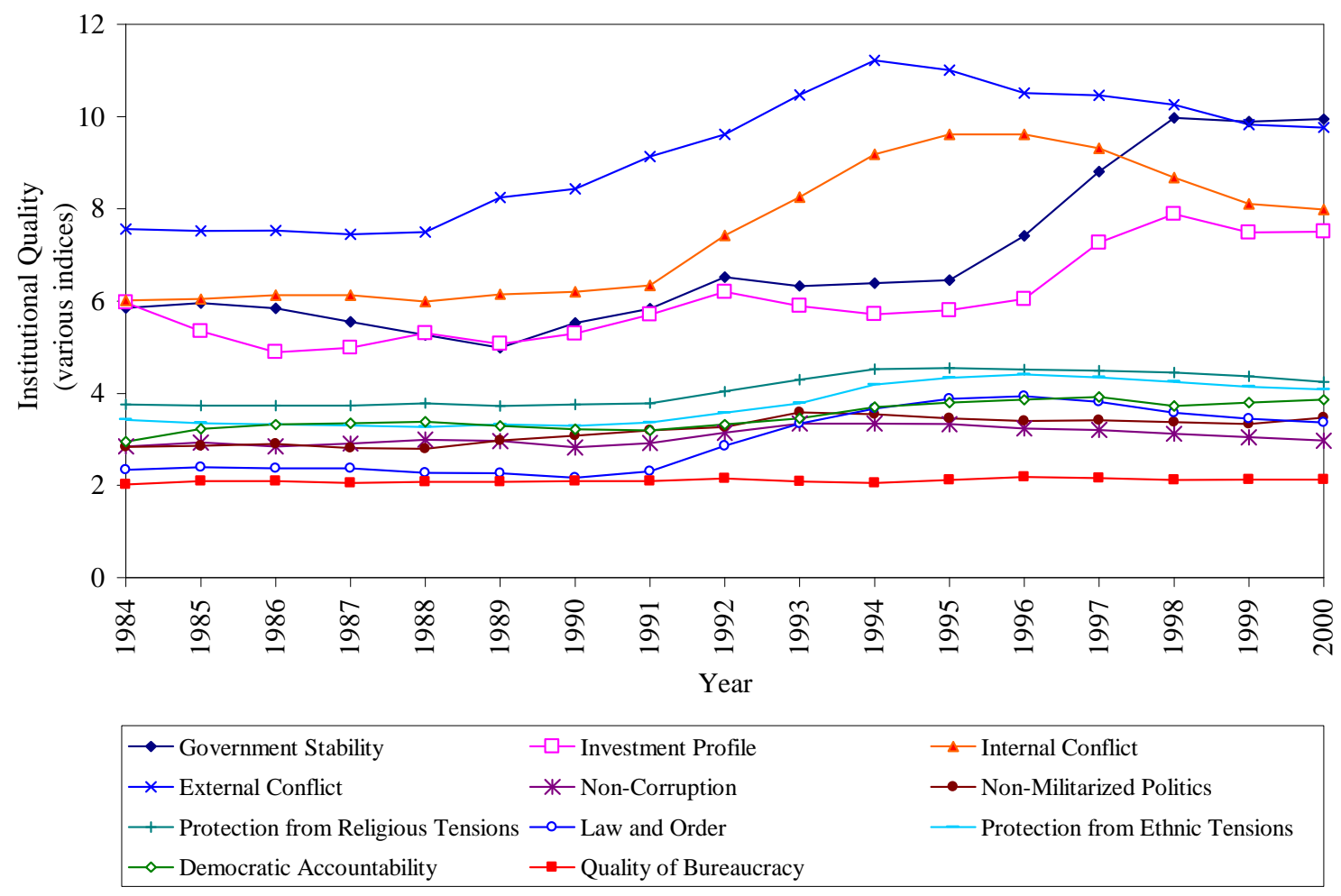

Notes: The developing countries are Bangladesh, Bolivia, Brazil, Cameroon, Chile, China, Colombia, Congo (Rep. of), Costa Rica, Dominican Rep., Ecuador, Egypt, El Salvador, Guatemala, Honduras, India, Indonesia, Iran, Israel, Jamaica, Korea (Rep. of), Malaysia, Mexico, Morocco, Nicaragua, Pakistan, Peru, Philippines, Senegal, South Africa, Sri Lanka, Syria, Thailand, Trinidad and Tobago, Tunisia, Turkey, Uruguay, and Venezuela. 
Figure 4: Conditional Correlation Plots from Regression of Inflows of Capital per capita on Institutional Quality and GDP per capita: Base Sample of 81 Countries

A. Correlation of Inflows of Capital per capita and Log GDP per capita after controlling for Institutional Quality

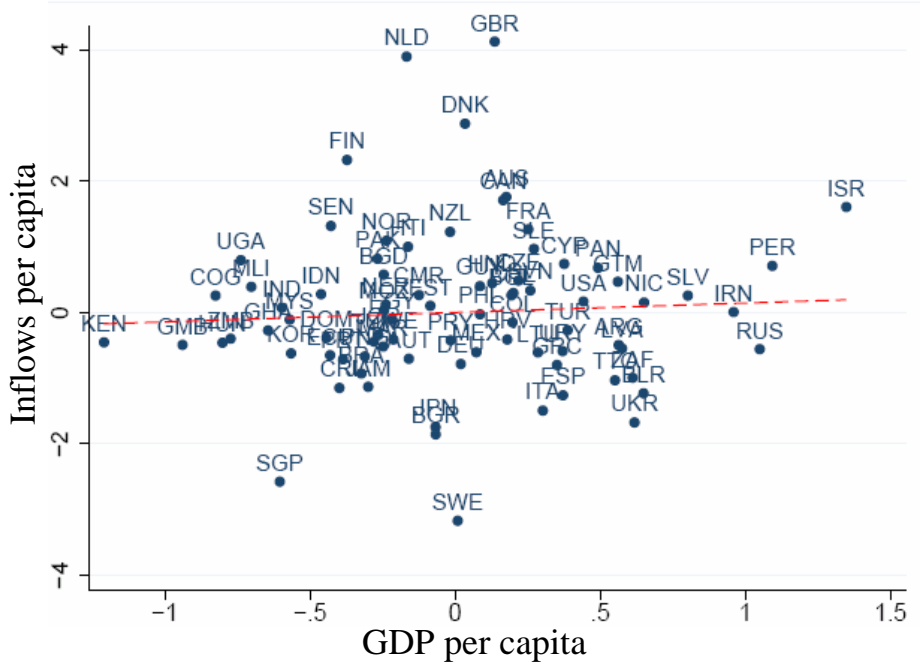

B. Correlation of Inflows of Capital per capita and Institutional Quality after controlling for Log GDP per capita

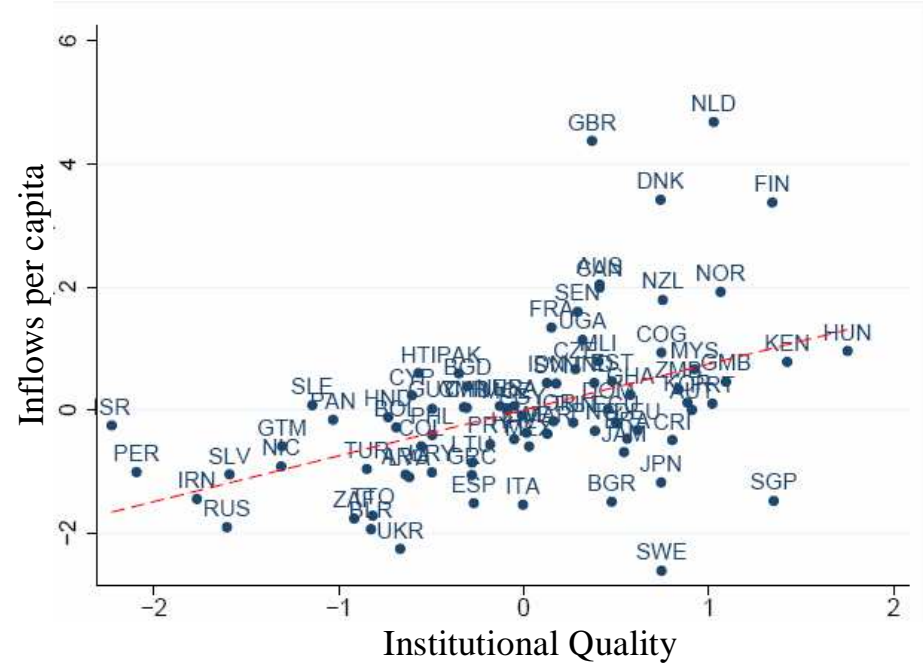

Notes: Inflows are inflows of direct and portfolio equity investment from the IMF, IFS in 1996 US\$. GDP per capita is 1996 PPP basis from PWT6.1. Panel A plots the residuals from the regression of average inflows of capital per capita, 1970-2000 on log of GDP per capita in 1970, the variable of interest, versus the residuals from the regression of log of GDP per capita in 1970 on average institutional quality, 1984-2000; a constant is included in both regressions. The line represents the fitted line from this regression. By Frisch-Waugh theorem, the coefficient in this regression is exactly the same as the coefficient on log GDP per capita in 1970 in the multiple regression including both log GDP per capita and institutional quality as reported in column (4) of table 5. Hence the slope of the line is 0.14. Panel B is constructed in the same fashion with institutional quality being the variable of interest, thus the slope of the line is 0.75 . 
Figure 5: Conditional Correlation Plots from Regression of Inflows of Capital per capita on Institutional Quality and Log GDP per capita: Base Sample of 58 Countries

A. Correlation of Inflows of Capital per capita and Log GDP per capita after controlling for Institutional Quality

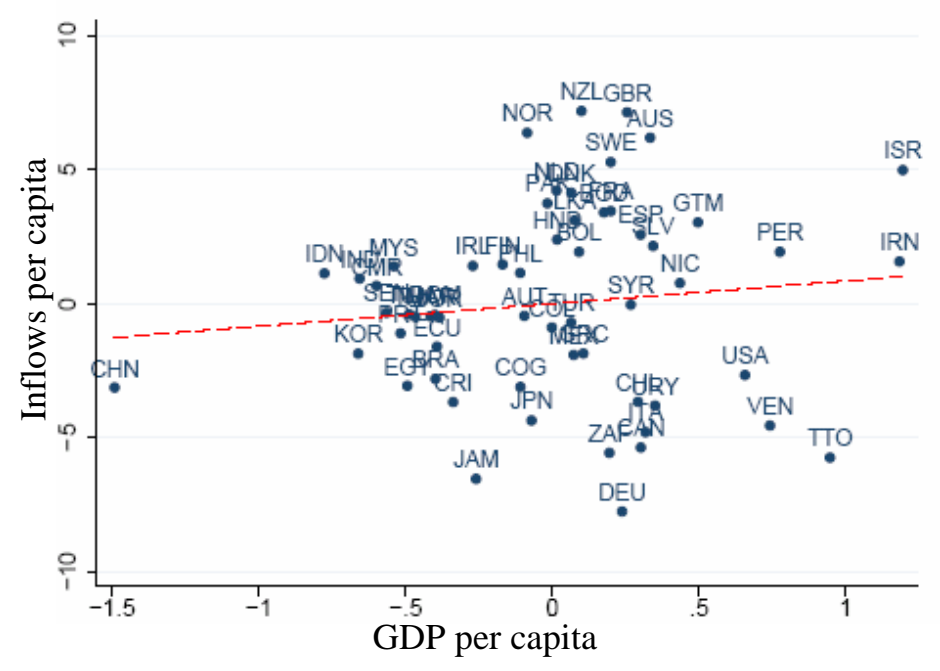

B. Correlation of Inflows of Capital per capita and Institutional Quality after controlling for Log GDP per capita

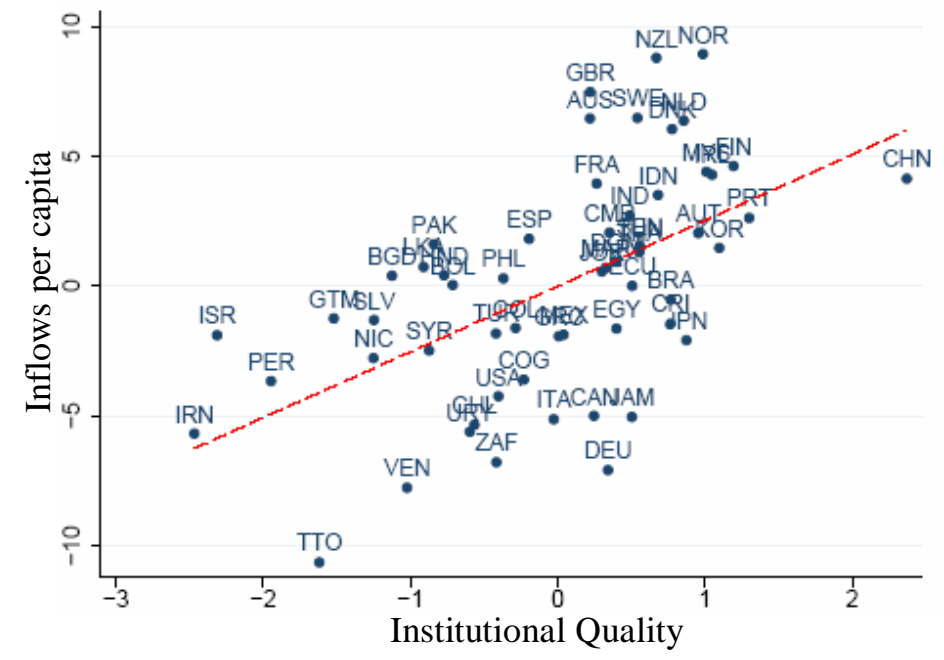

Notes: Inflows are calculated as the difference in stocks of FDI and portfolio liabilities from KLSV (2000) in 1990 US\$. GDP per capita is 1990 PPP basis from KLSV (2000). Panel A plots the residuals from the regression of average inflows of capital per capita, 1970-1997 on log of GDP per capita in 1970, the variable of interest, versus the residuals from the regression of log of GDP per capita in 1970 on average institutional quality, 1984-1997; a constant is included in both regressions. The line represents the fitted line from this regression. By Frisch-Waugh theorem, the coefficient in this regression is exactly the same as the coefficient on log GDP per capita in 1970 in the multiple regression including both log GDP per capita and institutional quality as reported in column (4) of table 7 . Hence the slope of the fitted line is 0.85 . Panel B is constructed in the same fashion with institutional quality being the variable of interest. The slope of this line is 2.54 . 
Figure C-1: Monte Carlo Distribution of Perturbed Regression Coefficients

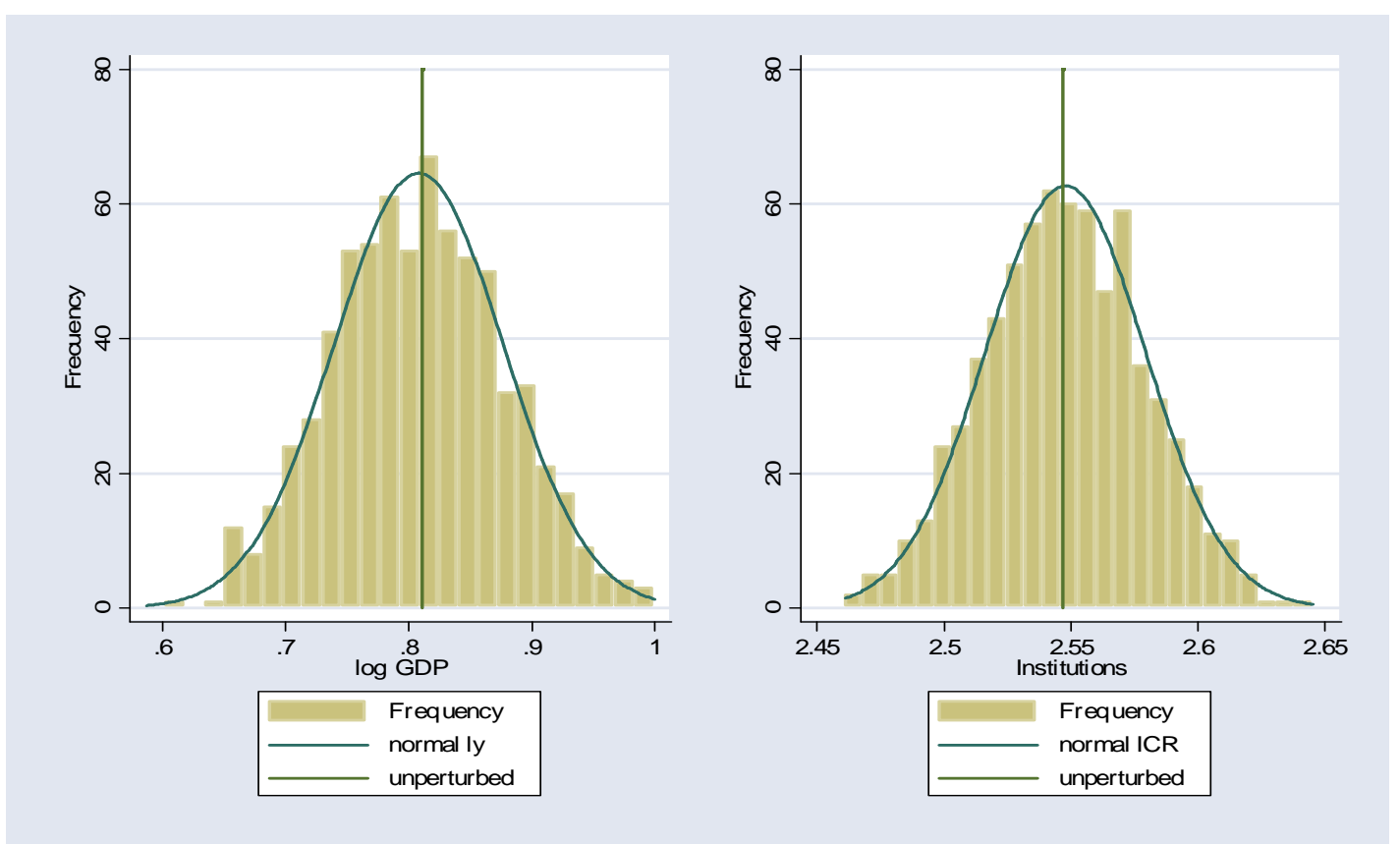

Notes: Figure displays the histogram of the distribution of "perturbed" coefficients from running the following regression 1000 times: $F_{i}=\mu^{\prime \prime}+\alpha^{\prime \prime} \log \left(Y_{i}+E\right)+\beta^{\prime \prime}\left(I_{i}+E\right)+\varepsilon_{i}^{\prime \prime}$, where $E$ denotes the added rounded error term (a rectangular distributed random number between -0.5 and +.499 in the digit after the first rounded decimal point). The unperturbed solution (vertical line) corresponds to the respective estimated coefficients using the actual data. The "normal line" is smoothing the distribution of 1000 observations. 